\title{
DOES FIRM-SPECIFIC INFORMATION IN STOCK PRICES GUIDE CAPITAL ALLOCATION?
}

\author{
Artyom Durnev \\ Randall Morck \\ Bernard Yeung
}

Working Paper 8093

http://www.nber.org/papers/w8093

\author{
NATIONAL BUREAU OF ECONOMIC RESEARCH \\ 1050 Massachusetts Avenue \\ Cambridge, MA 02138 \\ January 2001
}

We are grateful for helpful comments by Yakov Amihud, Serdar Dinc, Bjørne Jørgensen, Han Kim, Andrei Shleifer, Richard Sloan, Jeremy Stein, and Larry White; and to participants at the NBER Corporate Finance Seminar, Baruch-CUNY, Columbia Business School, Indiana University, the University of Michigan, MIT Sloan School, New York University, the University of North Carolina, and the University of Chicago. The views expressed herein are those of the authors and not necessarily those of the National Bureau of Economic Research.

(C) 2001 by Artyom Durnev, Randall Morck, and Bernard Yeung. All rights reserved. Short sections of text, not to exceed two paragraphs, may be quoted without explicit permission provided that full credit, including (C) notice, is given to the source. 
Does Firm-specific Information in Stock Prices Guide Capital Allocation?

Artyom Durnev, Randall Morck, and Bernard Yeung

NBER Working Paper No. 8093

January 2001

JEL No. G3

\begin{abstract}
We show that firms in industries in which firm-specific stock price variation is larger use more external financing and allocate capital with greater precision in the sense that their marginal q ratios are closer to one. According to the Efficient Markets Hypothesis, greater firm-specific stock price variation reflects higher intensity firm-specific information capitalization in stock prices. We propose that higher firm-specific price variation may be an indicator of greater functional-form market efficiency in the sense of Tobin (1982).
\end{abstract}

Artyom Durnev

Graduate Student

University of Michigan Business School

Ann Arbor, MI 48109

Tel: (734)763-6126

Email: adurnev@umich.edu
Randall Morck

Stephen A. Jarislowsky Professor of Finance Faculty of Business

University of Alberta

Edmonton, Alberta

Canada T6G 2R6

and NBER

Tel: (780)492-5683

Email: randall.morck@ualberta.ca

Bernard Yeung

Abraham Krasnoff Professor of International Business

and Professor of Economics

Stern School of Business

New York University

New York, NY 10012

Tel: (212) 998-0425

Fax: (212) 995-4221

Email: byeung@stern.nyu.edu 


\title{
Does Firm-specific Information in Stock Prices Guide Capital Allocation?
}

\author{
Artyom Durnev, Randall Morck, and Bernard Yeung
}

\section{Introduction}

The widespread success of the event study methodology in empirical corporate finance is consistent with firm-specific stock price movements reflecting the capitalization of new firmspecific information into share prices. The Efficient Markets Hypothesis (EMH) proposes that this capitalization occurs sufficiently quickly that stock prices track their fundamental (full information) values closely enough to prevent profitable arbitrage opportunities.

In this study, we explicitly choose the term 'information capitalization intensity', rather than stock returns variation, to emphasize the event study, or corporate finance, interpretation of stock returns variation as reflecting changes in the fundamental values of net corporate assets. The equivalence of these concepts is a fundamental axiom to financial economics. However, as Roll (1988) and French and Roll (1986) emphasize, the full implications of this equivalence, though economically important, are incompletely understood.

French and Roll (1986) and Roll (1988) find that most stock price variation in the U.S. is firm-specific, and reflects the capitalization of traders' private information. Black (1986) points 
out that information is not free and that more informed traders must therefore earn consistent positive returns in trading against the less informed to cover their information gathering and processing costs. In periods of high firm-specific price movements, both informed and uninformed traders may be active. It is unclear whether larger firm-specific price variation should be associated with stock prices closer to fundamental or further from them. Morck et al. (2000) propose that more intense capitalization of firm-specific information is associated with stock prices tracking fundamentals more closely. However, the alternative hypothesis, that a stock's price tracks its fundamental value more loosely during periods when substantial new information about that stock is being incorporated into its price, is perhaps more intuitively appealing - and so is our starting point.

The ability of stock prices to track firms' fundamental value is critical for resource allocations. Myers and Majluf (1984) show that when investors have less information than managers about fundamental values, they bid down the share prices of firms that undertake secondary securities issues. This is because investors know securities prices are not precisely equal to fundamental values, and presume that managers tend to issue new securities when the market price is too high. Thus, public investors react to announcements of secondary securities issues by revising downward their estimates of the values of those securities. This discount raises the cost of external financing to the firm's existing shareholders, and does so to a greater extent for securities whose prices track fundamentals more loosely. It follows that greater investor uncertainty about the accuracy of securities prices increases the likelihood of underinvestment because managers are unable to finance genuine value-enhancing projects. The overall inference is that firms whose shares track fundamentals more precisely can obtain external financing more cheaply and are less likely to exhibit signs of underinvestment. 
Myers and Majluf (1984) propose that firms should retain sufficient 'financial slack' to fund positive NPV projects internally; however, Jensen (1986) argues that the cure may often be worse than the disease. Excessive financial slack increases the likelihood of overinvestment because it frees managers from capital market oversight, creating agency problems such as 'empire building' negative NPV investment by hubristic CEOs. The overall inference is that firms whose shares track fundamentals less precisely might be as likely to exhibit overinvestment as underinvestment.

Thus, investor uncertainty about asset prices leads ultimately to underinvestment, overinvestment, or both in various firms throughout the economy. Hayek (1941) argues that such microeconomic misallocation of capital is pervasive, and a serious economic problem even in the absence of aggregate overinvestment or underinvestment. We follow Hayek (1941) in using the term 'malinvestment' to describe either undertaking value-destroying projects or declining to undertake value-enhancing projects, or both. Tobin (1982) argues that the EMH is important primarily because more meaningful stock prices plausibly allow for improved microeconomic capital allocation, and refers to this linkage as the 'functional' form of the EMH.

The above considerations lead us to explore the empirical relationship between the intensity of capitalization of firm-specific information, measured by firm-specific stock price variability, and both the use of external funds and measures of malinvestment. These types of corporate finance behavior clearly depend on macroeconomic conditions as well as the institutional and legal environment. Using cross-sectional data from one country, US, we hold constant the influence of these factors.

Our data generate the overriding result that industries in which stock returns exhibit greater firm-specific variation use more external financing and show less evidence of malinvestment, in that their marginal $q$ ratios are closer to one, and their average $q$ ratios are 
higher. These results survive controlling for firm-specific fundamentals variation directly, and for industry characteristics plausibly associate with fundamentals volatility.

We therefore cautiously endorse the suggestion of Morck et al. (2000) that more intense capitalization of firm-specific information is associated with stock prices tracking fundamentals more closely.

The rest of this paper is organized as follows. Section 2 describes our empirical methodology and data. Section 3 describes the construction of the stock variation measures. Section 4 and 5 present our findings of statistically meaningful relationships between the intensity of firm-specific variation and both external financing and the quality of capital budgeting. Section 6 considers a possible interpretation of our findings. Section 7 concludes.

\section{Empirical Framework and Data}

\section{Empirical Framework}

Our basic empirical procedure is to run regressions explaining corporate financial decision-making on measures of information capitalization intensity and control variables. We aggregate firm-level data on publicly traded US corporations to construct the industry-level variables used in the regressions. The first set of corporate finance variables we consider gauges the proportion of capital expenditures supported by external financing. The second set measures the quality of capital budgeting decisions.

We use industry aggregates for three reasons. First, capital budgeting and access to outside financing may affect firm entry and exit. By aggregating to industry-level data, we automatically capture the gross result of such evolution. Dealing with firm entry and exit is a challenging problem, which we relegate to future research. Second, industry aggregates let us pool cross-section and time-series data to construct more reliable estimates for our dependent 
variables, particularly our proxies for the quality of capital budgeting decisions. Third, industry aggregates are less affected by error in variables problems due to reporting errors and the like. It turns out that results based on firm-level regressions are very similar to the industry-level regressions we report below. We shall also describe them wherever appropriate.

Our empirical framework is also designed to minimize other possible sources of bias. First, scaling the use of external financing by capital expenditure mitigates the influence of the availability of exogenous investment opportunities. Second, to mitigate endogeneity problems, we use the lagged value (predetermined and historical) of the measures of information capitalization intensity. It turns out that using contemporaneous data does not materially affect our results. We describe such results in our robustness discussions.

\section{Data}

Our sample begins with all companies listed in CRSP from 1990 to 1992 . We discard duplicate entries for preferred stock, class B stock, and the like by deleting entries whose CUSIP identifiers CRSP appends a number other than 10. We match these companies with those listed in Standard and Poor's annual COMPUSTAT tapes, and delete four firms that report negative sales. Because CRSP and COMPUSTAT occasionally assign the same firm different CUSIP identifiers, we visually inspected the lists of unmatched firms in both. Where company name matches (or near matches) are evident, we check the CRSP permanent identification number, ticker symbols and stock prices to reject false matches. This matching procedure adds 165 firms to our firm-level full sample, leaving 6 firms listed in COMPUSTAT but not CRSP and 14 firms in CRSP but not COMPUSTAT. We discard these.

Since the analysis below requires more than one firm in each industry, we drop seven industries that contain three or fewer firms. Since accounting variables for financial and banking 
industries (SIC codes from 6000 through 6999) are not comparable to those of non-financial industries we exclude the former. Regulated utilities (SIC 4900 through 4999) are arguably subject to different investment constraints than unregulated firms, though liberalization in the 1980s may have mitigated this difference to some extend. Although we leave utilities in our sample of industries, dropping them does not qualitatively change our results.

Finally, we drop firm-year observations with fewer than thirty days of daily stock returns data. When firms are delisted and COMPUSTAT indicates that a bankruptcy occurred, we assume a final daily return of minus $100 \%$. When firms are delisted and COMPUSTAT indicates that a corporate control event occurred the final return is taken as given.

After these procedures, our final '1990 to 1992 sample' contains 6,021 firms spanning 214 three-digit SIC industries. We use this sample to construct our information capitalization intensity variables and most of our control variables.

Constructing some control variables requires a longer panel prior to 1993 . For these, we expand the 1990 to 1992 sample backward to 1983 by keeping sample firms that remain listed in listed in COMPUSTAT in the period demarcated by those years. This '1983 to 1992 sample' contains 5,680 firms spanning 214 industries.

We use data from a '1993 to 1997 sample' to construct our corporate finance decision variables. This sample consists of all firms listed in COMPUSTAT during those years in the industries spanned by our 1990 to 1992 sample. Our final 1993 to 1997 sample contains 6,375 firms spanning 214 three-digit industries.

When COMPUSTAT reports a value as 'insignificant' we set it to zero. When companies change their fiscal years, COMPUSTAT records one fiscal year with fewer than twelve months and another with more than twelve months. Under some circumstances, this causes COMPUSTAT to report a missing year observation. If a firm's fiscal year ends before 
June 15th, COMPUSTAT reports it as data for the previous year on the grounds that more than half of the fiscal year occurred in the previous calendar year. This convention causes missing values if no fiscal year has the majority of its months in the calendar year of the change. We drop those firms.

In all samples, we define industries as sets of firms that share the same primary threedigit SIC code in the COMPUSTAT Business Segment database. Firms need not have data for all time periods to be included in any of the samples; so all are unbalanced panels.

\section{Firm-specific Information Capitalization Intensity Measures}

We assume firm-specific stock returns to be driven by the capitalization of firm-specific information, which French and Roll (1986) and Roll (1988) show to be mainly private information. Our measures of the intensity with which firm-specific information is capitalized into stock returns are fashioned after those of Morck, Yeung and Yu (2000), and are described in this section. We follow French and Roll (1986) and Roll (1988) in interpreting firm-specific stock return as the capitalization of private firm-specific information. These variables are constructed from daily stock returns data in the 1990 to 1992 sample described above. This choice of years gives us a large enough panel of annual data to construct the control variables described below, yet also lets us to relate our information capitalization intensity variables to subsequent corporate finance decisions. Because we are interested in average information capitalization intensity, we use firm-level data to estimate these variables for each industry. 


\subsection{Absolute Firm-specific Information Capitalization Intensity}

To measure the absolute magnitude of firm-specific variation in the stock prices of firms in an industry, we isolate firm-specific return variation from industry-related or market-related variation. We thus run the regression

$$
r_{j, t}=\beta_{j, 0}+\beta_{j, m} r_{m, t}+\beta_{j, i} r_{i, t}+\varepsilon_{j, t}
$$

for each firm $j$, where $t$ is a daily time index over the period from 1990 through 1992, $r_{j, t}$ is firm $j$ 's stock return, $r_{m, t}$ is a market return, and $r_{i, t}$ an industry return for industry $i$ (which contains firm $j$.

Although regression [1] resembles standard asset pricing equations, we do not emphasize this. Our purpose is not to explain a relationship between returns and systematic risk, but to understand the economic importance of firm-specific stock price variation. Stock price variation associated with macroeconomic or industry information is of interest to us primarily as a control variable.

The market index and industry indexes in [1] are value-weighted averages excluding the firm in question. This exclusion prevents spurious correlations between firm returns and industry returns in industries that contain few firms. Thus,

$$
r_{i, t}=\frac{1}{J_{i}-1}\left(\sum_{k \in i} w_{k, t} r_{k, t}-w_{j, t} r_{j, t}\right)
$$

with $w_{k, t}$ the value-weighting of firm $k$ in the index and $J_{i}$ the number of firms in industry $i$.

Denote the unexplained variation of regression [1] for firm $j$ as $S S R_{j}$. An average of the unexplained variation across all firms $j$ in industry $i$, weighted by the number of daily return observations for each firm, $T_{j}$, is

$$
\sigma_{\varepsilon, i}^{2}=\frac{\sum_{j \in i} S S R_{j}}{\sum_{j \in i} T_{j}}
$$


Since $\sigma_{\varepsilon, i}^{2}$ is highly skewed (skewedness $=5.31$ ) and leptokurtic (kurtosis $=40.7$ ), we apply a logarithmic transformation. We use the Greek letter omicron to denote our estimate of the absolute firm-specific information capitalization intensity of industry $i$,

$$
\Theta_{i}=\ln \left(\sigma_{\varepsilon, i}^{2}\right)
$$

The distribution of $\Theta_{i}$ is more symmetric (skewedness $=0.163$ ) and less leptokurtic (kurtosis $=$ 4.11).

\subsection{Relative Firm-specific Information Capitalization Intensity}

An alternative way to measure the intensity of firm-specific information capitalization is relative to the sum of the intensities of industry- and market-related information capitalization. Our measure of the this sum is based on the explained variation from regression [1]. Define

$$
\sigma_{m, i}^{2}=\frac{\sum_{j \in i} S S M_{j}}{\sum_{j \in i} T_{j}}
$$

where $S S M_{j}$ is the sum of squared variation in $r_{j}$ explained by the model in regression [1] for firm

$j$ in industry $i$. This variable is again asymmetrically distributed (skewedness $=5.30$ ) and leptokurtic (kurtosis $=36.7$ ). We again employ a logarithmic transformation and denote the absolute intensity of industry- and market related information capitalization in industry $i$ by the Scandinavian letter $o e$,

$$
\varnothing_{i}=\ln \left(\sigma_{m, i}^{2}\right)
$$

Again, the resulting distribution is more symmetric (skewedness $=0.515$ ) and less leptokurtic (kurtosis $=4.59)$.

A higher $\varnothing_{i}$ indicates an industry in which stock prices fluctuate because of the capitalization of a higher intensity stream of information related to market and industry events. 
If investors' information flows about some industries are more intense than about other industries, this may be reflected in generally higher returns variation. Our focus is firm-specific information capitalization, so $\varnothing_{i}$ is a useful benchmark for gauging the relative magnitude of $\Theta_{i}$. Including $\varnothing_{i}$ as a control variable in regressions explaining $\Theta_{i}$ lets us ask whether greater firmspecific variation $\Theta_{i}$ is associated with more outside financing and better capital budgeting after controlling for the intensity of the information flow regarding that industry and the economy as a whole.

Our relative firm-specific information capitalization intensity measure incorporates this benchmarking explicitly. Define

$$
R_{i}^{2}=\frac{\sigma_{m, i}^{2}}{\sigma_{\varepsilon, i}^{2}+\sigma_{m, i}^{2}}
$$

This measure can be interpreted as if it were the $R^{2}$ of a regression, in that it measures returns variation explained by market and industry returns relative to total variation. We interpret $R_{i}^{2}$ as measuring the importance of systematic industry- and market-wide information in total stock return variation. It follows that one minus $R_{i}^{2}$ is an analogous measure of the relative importance of firm-specific information capitalization.

The distribution of $1-R^{2}$ is negatively skewed (skewedness $=-0.911$ ) and mildly leptokurtic (kurtosis $=4.64$ ). It also has the econometrically undesirable characteristic of being bounded within the unit interval. As recommended by Theil (1971, chapter 12), we circumvent the bounded nature of $R^{2}$ by applying a logistic transformation

$$
\Psi_{i}=\ln \left(\frac{1-R_{i}^{2}}{R_{i}^{2}}\right)
$$


taking $1-R_{i}^{2} \in[0,1]$ to $\Psi_{i} \in \mathbf{R}$. We thus use the Greek letter psi to denote firm-specific information capitalization intensity measured relative to industry- and market-related information capitalization intensity. The transformed variable is again less skewed (skewedness $=$ 0.239) and less leptokurtic (kurtosis $=3.869$ ). The hypothesis that $\Psi_{i}$ is normally distributed cannot be rejected in a standard W-test $(p$-val $=0.14)$.

The $\Psi_{i}$ also possess the useful trait that they are simple differences between $\Theta_{i}$ and $\varnothing_{i}$ since

$$
\Psi_{i}=\ln \left(\frac{1-R_{i}^{2}}{R_{i}^{2}}\right)=\ln \left(\frac{\sigma_{\varepsilon, i}^{2}}{\sigma_{m, i}^{2}}\right)=\ln \left(\sigma_{\varepsilon, i}^{2}\right)-\ln \left(\sigma_{m, i}^{2}\right)=\Theta_{i}-\varnothing_{i}
$$

Intuitively, the higher the value of $\Psi_{i}$, the more important is firm-specific variation, $\sigma_{\varepsilon, i}^{2}$, relative to market and industry-wide variation, $\sigma_{m, i}^{2}$, in explaining the stock price movements of firms in industry $i$.

For simplicity of exposition, we follow the finance literature in referring to $\sigma_{\varepsilon, i}^{2}$ as 'firmspecific returns variation,' and $\sigma_{m, i}^{2}$ as 'systematic returns variation'. We refer to $\Theta_{i}$ as the 'intensity of firm-specific information capitalization' and $\varnothing_{i}$ as the 'intensity of systematic information capitalization' to emphasize the event study, or corporate finance, interpretation of stock returns variation as reflecting the capitalization of information about 'events' that affect firms. This terminology is consistent with finance theory, in that under the Efficient Markets Hypothesis, 'returns variation' and the 'intensity of information capitalization' are close to synonymous. Finally, we refer to $\Psi_{i}$ as the intensity of firm-specific information capitalization 
relative to systematic information capitalization,' or simply as the 'relative intensity of firmspecific information capitalization.' ${ }^{1}$

Table 1 contains brief descriptions of these variables, and of all other variables used in this study. Panel A of Table 2 shows the mean, median, standard deviation, minimum and maximum of each measure of information capitalization intensity $\left(\Theta_{i}, \varnothing_{i}\right.$, and $\left.\Psi_{i}\right)$. The substantial standard deviations of all three measures and the substantial difference between their minimum and maximum values attest to the variation of these measures across industries. Higher intensity firm-specific and systematic information capitalization tend to occur together $\left(\rho_{\Theta \varnothing}=0.782, p-v a l=0.00\right) .^{2}$

Our basic econometric procedure is to run regressions explaining variables $\Omega_{i}$, which reflect corporate financial decisions taken by firms in industry $i$, on our information capitalization intensity measures and control variables. The first set of corporate finance variables we consider reflects the use of external financing as a fraction of capital expenditure. The second set measures the quality of capital budgeting decisions.

These regressions are either of the form

$$
\Omega_{i}=b_{\Theta} \Theta_{i}+b_{\varnothing} \varnothing_{i}+\mathbf{c} \cdot \mathbf{Z}_{\mathbf{i}}+u_{i}
$$

where absolute firm-specific information capitalization intensity in industry $i$ is measured by $\Theta_{i}$, with $\varnothing_{i}$ as an additional control, or of the form

$$
\Omega_{i}=b_{\Psi} \Psi_{i}+\mathbf{c} \cdot \mathbf{Z}_{\mathbf{i}}+u_{i}
$$

\footnotetext{
${ }^{1}$ We depart from the standard terminology of asset pricing in that we follow Roll (1988) in distinguishing 'firmspecific' variation from the sum of market-related and industry-related variation. For simplicity, we refer to the latter sum as 'systematic' variation, though this is not strictly correct.

${ }^{2}$ In our sample, examples of high firm-specific information capitalization intensity industries include: commercial sports, knitting mills, crude petroleum \& natural gas, periodical publications, and tobacco. Examples of low firmspecific information capitalization intensity industries include engines and turbines, general building constructors, department stores, drug and proprietary stores, electric, gas and other services (regulated industries), and operative builders.
} 
with relative firm-specific information capitalization intensity measured by $\Psi_{i}$. The vector $\mathbf{Z}_{\mathbf{i}}$ contains control variables.

\section{Firm-specific Information Capitalization and External Financing}

The first corporate finance variables we consider measure the proportion of capital expenditure financed with external funds. We use these variables to test for a relationship between the intensity of firm-specific information capitalization in stock prices and the extent to which firms use external capital.

\subsection{External Financing Measures}

We consider several measures of an industry's use of and need for external financing. These are the values of: net long-term debt issued, denoted $\Delta l d_{i}$; net equity issued, $\Delta e_{i}$; net shortterm debt issued, $\Delta s d_{i}$; net long-term debt and equity issued, $\Delta l d \& e_{i}$; and net debt and equity issues, $\Delta d \& e_{i}$. All of these measures are normalized by dividing by capital spending, and so are best interpreted as measuring the extent to which external financing of various types covers firms' capital budgets.

It may be inappropriate to include short-term debt because companies run lines of credit or accounts payable up and down substantially in the course of normal business operations. However, trade credit and bank loans are clearly important sources of external financing in some industries. We therefore include short-term debt in some, but not all, of the analysis below.

We truncate these variables at zero and one so that they measure the fractional coverage of capital expenditure by external financing. This truncation means we consider net repurchases as equivalent to no coverage of the capital budget by that type of security, and net issues exceeding the capital budget as equivalent to full coverage of the capital budget by issues of that 
type of security. We follow this procedure in order to limit the statistical influence of industries with very small capital budgets and industries undergoing major capital structure adjustments. We recognize that this truncation itself causes some econometric difficulties. We discuss these issues, and rerun the regressions on untruncated data as a robustness check.

The following paragraphs provide details on the construction of our external financing measures, and can be skipped without loss of continuity.

\section{Construction of the External Financing Measures}

Let $L D_{j, t}$ be the book value of long-term debt issued by firm $j$ in industry $i$ during year $t \in$ [1993,1997], as reported in COMPUSTSAT. Our primary measure of the extent to which new debt covers industry $i$ 's capital spending costs is

$$
\Delta l d_{i}=\max \left[0, \min \left[\frac{\sum_{j \in i, t \in[1993,1997]} \Delta L D_{j, t}}{\sum_{j \in i, t \in[1993,1997]} \Delta X_{j, t}}, 1\right]\right]
$$

where $\Delta L D_{j, t}=\Delta L D_{j, t}-\Delta L D_{j, t-1}$ is the net new issue of long-term debt and $\Delta X_{j, t}$ is the total value of capital spending of firm $j$ (in industry $i$ ) in year $t$. This variable is bounded within the unit interval.

Let $\Delta E_{j, t}$ be net new equity issues by firm $j$ (in industry $i$ ), again from 1993 to 1997 . The fractional coverage of industry $i$ capital expenditure by new equity issues is defined analogously as

$$
\Delta e_{i}=\max \left[0, \min \left[\frac{\sum_{j \in i, t \in[1993,1997]} \Delta E_{j, t}}{\sum_{j \in i, t \in[1993,1997]} \Delta X_{j, t}}, 1\right]\right.
$$

This variable is similarly bounded within the unit interval. 
One more form of outside capital is short-term debts, which often takes the form of bank loans and trade credit. We capture these by summing short-term debts and account payable from the balance sheets of all firms $j$ in industry $i$. Let $\Delta S D_{j, t}$ be the change in this sum. The extent to which new short-term debt covers industry $i$ 's capital spending costs is:

$$
\Delta s d_{i}=\max \left[0, \min \left[\frac{\sum_{j \in i, t \in[1993,1997]} \Delta S D_{j, t}}{\sum_{j \in i, t \in[1993,1997]} \Delta X_{j, t}}, 1\right]\right]
$$

We examine also the fractional coverage of capital investment by new long-term debt and new equity combined. Since some firms may issue debt to repurchase equity or vice versa, the simple sum of $\Delta l d_{i}$ and $\Delta e_{i}$ may overstate an industry's actual need for external funds to cover capital spending. We therefore construct a combined measure of the extent to which both longterm debt and equity are issued to pay for new capital spending as

$$
\Delta l d \& e_{i}=\max \left[0, \min \left[\frac{\sum_{j \in i, t \in[1993,1997]}\left(\Delta L D_{j, t}+\Delta E_{j, t}\right)}{\sum_{j \in i, t \in[1993,1997]} \Delta X_{j, t}}, 1\right]\right]
$$

and again truncate it to lie within the unit interval.

Analogously, we construct a combined measure of the extent to which total (long and short-term) debt and equity cover an industry's cost of new capital spending as:

$$
\Delta d \& e_{i}=\max \left[0, \min \left[\frac{\sum_{j \in i, t \in[1993,1997]}\left(\Delta L D_{j, t}+\Delta S D_{j, t}+\Delta E_{j, t}\right)}{\sum_{j \in i, t \in[1993,1997]} \Delta X_{j, t}}, 1\right]\right]
$$

In constructing these variables, we assume debt or equity issues to be nil if these variables are not reported in COMPUSTAT but all major financial variables are reported. 


\subsection{Simple Correlations}

Univariate statistics are presented in Panel B of Table 2. Table 3a shows all five external financing measures to be significantly positively associated with the absolute magnitude of firmspecific information capitalization intensity, $\Theta$. Four of them $(\Delta l d, \Delta e$, and $\Delta l d \& e, \Delta d \& e)$, which all involve long-term market-based financing (long-term debt and equity), are also positively significantly related to firm-specific relative to systematic information capitalization intensity, $\Psi_{i}$. Positive correlations with systematic information capitalization intensity, $\varnothing_{i}$, are also evident, but with smaller coefficients, so the correlations with $\Psi_{i}$ are also positive and significant. In contrast, $\Delta s d$ is positively correlated with industry and market related information capitalization intensity, rendering it uncorrelated with $\Psi$.

In summary, a higher intensity of firm-specific information capitalization is associated with more use of external funds, not less, as we initially hypothesized.

\subsection{Control Variables}

Before we can infer an economically meaningful positive relationship between the use of external financing and the intensity of firm-specific information capitalization, we must control for other industry characteristics that might be correlated with information capitalization intensity and that might influence the use of external financing. This is important because firmlevel economic fundamentals might naturally move more in synch with market or industry conditions in some industries than in others for reasons that might also affect the use of external financing. For example, mature industries may generate more internal cash flow than young industries. Since mature industries often produce standardized commodities, they may be composed of relatively homogenous firms, whose share prices and fundamentals may exhibit 
relatively little firm-specific variation. Indeed, any factor that might affect both the homogeneity of firms within an industry and that industry's use of external financing could generate a spurious correlation.

We therefore include as specialized control variables proxies for several such factors. However, the list of possible factors that might affect both information capitalization and the use of external funds is long, and our proxies may be imperfect. We therefore also measure the firmspecific volatility of fundamentals directly, and include measures of this as 'catch all' general control variables. In addition, we check the robustness of our results by substituting different versions of these controls.

\section{Specialized Control Variables}

First, we ought to control for industry size. Firms in large, established industries and small, new industries might have different access to, and need for, external funds. Since large firms disproportionately affect industry and market indexes, a spurious correlation is possible. Our primary measure of industry size is the logarithm of the estimated real replacement cost of fixed capital (property, plant and equipment), averaged across 1990, 1991 and 1992, denoted $\ln \left(K_{i}\right)$. Because historical cost accounting makes simple deflators questionable in adjusting for inflation, we use a recursive inflation adjustment formula to convert reported figures to 1983 dollars. We assume that physical assets depreciate by ten percent a year. Let $K_{j, t-10}$ be the book value of net $P P \& E$ (in 1983 dollars) for firm $j$ in year $t$. (If a company's history is shorter than ten years, we start the rolling equation with the first year available.) $P P \& E$ in year $t-9$ is then

$$
\begin{gathered}
K_{j, t-9}=(1-\delta) K_{j, t-10}+\frac{\Delta X_{j, t-9}}{1+\pi_{t-9}} \text {. More generally, we apply the recursive equation } \\
K_{j, t+1}=(1-\delta) K_{j, t}+\frac{\Delta X_{j, t+1}}{\prod_{\tau=0}^{t+1}\left(1+\pi_{\tau}\right)}
\end{gathered}
$$


Thus, PP\&E in year $t+1$ is PP\&E from year $t$ minus $10 \%$ depreciation plus current capital spending, denoted $\Delta X_{j, t+1}$, deflated to 1983 dollars using $\pi_{t}$, the fractional change in the seasonally adjusted producer price index fr finished goods published by the U.S. Department of Labor, Bureau of Labor Statistics. ${ }^{3}$

Second, market structure might matter. Monopoly rents elevate internal cash flows and, all else equal, decrease the need for funds from outside. Since firms in more monopolistic industries might also be less transparent to investors, a spurious correlation is possible. At the same time, surviving firms in industries dominated by a few firms may be seen to have more stable and secured cash flows and thus be more able to obtain outside debt. To control for market structure, we use standard industry Herfindahl indices, denoted $H_{i}$, based on real sales averaged over 1990 to 1992.

Third, firms in industries where intangible assets are important, all else equal, have fewer assets that can serve as collateral for loans and bond issues. Since the values of intangible assets may also be affected differentially by industry or macroeconomic events, a spurious correlation is again possible. To control for the importance of intangibles in an industry, we include two control variables: industry research and development (R\&D) spending and industry advertising spending, denoted $r \& d$ and $a d v$ respectively. Both are measured per dollar of tangible assets in each industry measured across our 1990 to 1992 sample. Tangible assets are real property, plant and equipment, as estimated recursively in [17], plus real inventories. ${ }^{4}$ A firm's R\&D or advertising is considered to be negligible if not reported and all other financial data are reported.

\footnotetext{
3 This index is available at http://www.stls.frb.org/fred/data/ppi/ppifgs.

${ }^{4}$ Historical cost accounting makes the use of simple deflators problematic in estimating real inventories. Standard inventory accounting methods also complicate inflation adjustments. We convert the last-in-first-out (LIFO) component of inventories to market value by using past inventory changes to estimate the age profile of each firm's inventories. Inventories are assumed to reflect market value in the firm's first year of COMPUSTAT data. Then, a recursive process, similar to that in [17], is used to estimate the age structure of LIFO inventories. LIFO inventories of each age are then individually adjusted for inflation using the GDP deflator.
} 
Fourth, corporate diversification might matter because it affects both stock return variation and the need for external financing. ${ }^{5}$ To construct a proxy for firm diversification, we count the number of different 3-digit industry segments in which a firm operates in 1990-1992 according to the Compustat Industry Segment Data Tape. The diversification index for industry $i$, which we denote $d s_{i}$, is the 1990-1992 average of asset-weighted averages of firm level diversification across that industry.

Fifth, general levels of liquidity might matter. Different industries require different degrees of liquidity in the course of normal business activity. For example, industries subject to more fundamentals shocks might, ceteris paribus, hold larger cash cushions. Normal holdings of liquid assets could affect both firms' need for external funds and their ability to raise then.

To control for industry liquidity norms, we therefore use net current assets as a fraction of total assets

$$
\lambda_{i}=\frac{\sum_{j \in i, t \in[1990,1992]} \text { current assets }_{j, t}-\text { current liabilities }_{j, t}}{\sum_{j \in i, t \in[1990,1992]} \text { tangible assets }_{j, t}}
$$

for each industry $i$ for the years from 1990 through 1992, where firm $j$ is in industry $i$. The denominator is real property, plant and equipment, estimated using the recursive procedure in [17], plus real inventories.

Sixth, firms' new financing decisions could depend on their existing capital structures. Firms that already have highly leveraged capital structures might be less likely to use new debt

\footnotetext{
${ }^{5}$ Lewellan (1971) proposes that diversification stabilizes earnings, and helps firms access debt financing on better terms, all else equal. Matsusaka and Nanda (1994) and Stein (1997) argue that the head office of a diversified firm can act like financial intermediary, investing surplus funds from one division in positive NPV projects in another, reducing the need for external funds. Amihud and Lev (1981), Morck et al. (1990), May (1995), and Khorana and Zenner (1998) all propose that managerial utility maximization might explain value-destroying diversification, so more diversified firms might be firms with larger agency problems. Scharfstein and Stein (1997) argue that diversified firms shift income from cash rich divisions to cash poor ones out of a sense of "fairness". Rajan et al. (1998) propose that such transfers are due to self-interested divisional managers and weak head offices. Thus, different levels of corporate diversification could conceivably generate a spurious correlation between financing decisions and information capitalization intensity in several ways.
} 
and more likely to use additional equity financing. Also, high existing debt level might reflect recent extensive new debt financing, and so might presage a period of relatively scant additional debt issuance. In addition, Jensen (1986) argues that high leverage improves corporate governance. Since high leverage increases the variation in stock return, and thus $\Theta_{i}$, and $\varnothing_{i}$, any such effects might create a bias in our simple correlations. We therefore include as an additional control variable each industry's asset-weighted average leverage, denoted $l e v_{i}$, and defined as the market value of total long-term debt, estimated recursively from historical changes in book values assuming 15 year bonds issued at par, scaled by tangible assets, estimated using [17], for $1992 .^{6}$

Seventh, some industries may be more suitable as issuers of some kinds of securities. For example, natural resources firms can readily issue secured debt using their proven reserves as collateral. Software firms, in contrast, have few collateralizable assets. To control for such industry characteristics, we include one-digit industry fixed effects. We discuss other approaches to controlling for industry effects when we discuss the robustness of our results.

Several other specific control variables are also considered in the robustness section below.

\section{General Control Variables}

Each of the above control variables captures a plausible relationship between firmspecific fundamentals variation and the use of external funds. Unfortunately, the number of such plausible relationships is large, and many are not amenable to capture by control variables. We

\footnotetext{
${ }^{6}$ We construct a fifteen-year age profile of each firm's debt each year based on changes in book values. We then estimate the market value of each vintage of each firm's debt in each year assuming all bonds to be 15 year coupon bonds issued at par. We use Moody's baa bond rates to proxy for all bond yields.
} 
therefore also include a general control variable that directly gauges the correlation of firm-level fundamentals with industry and market fundamentals.

To measure fundamentals correlation, we follow Morck, Yeung and Yu (2000) and construct variables analogous to our stock return variation measures $\psi, \Theta$, and $\varnothing$, but using annual returns on assets $(R O A)$ estimates,

$$
R O A_{j}=\frac{\text { income }_{j}+\text { depreciation }_{j}+\text { interest }_{j}}{\text { tangible assets }_{j}}
$$

The numerator of [19] is inflation adjusted using the GDP deflator. The denominator is real property, plant and equipment, estimated using the recursive procedure in [17], plus real inventories.

\section{Construction of Fundamentals Co-movement Variables}

We require estimates of the firm-specific and systematic (market- and industry-related) components of the firm-level variation in return on assets within each industry. To obtain these, we run firm-level regressions of the form of [1] using ROA rather than stock returns. That is, we run

$$
R O A_{j, t}=\beta_{j, 0}+\beta_{j, m} R O A_{m, t}+\beta_{j, i} R O A_{i, t}+\varepsilon_{i, t}
$$

for each firm $j$ in each industry $i$ represented in our 1983 to 1992 sample with $t$ an annual time index, $R O A_{j, t}$ firm $j$ 's $R O A, R O A_{m, t}$ a value weighted $R O A$ index for the market, and $R O A_{i, t}$ a

value weighted industry $R O A$ index. Again, we calculate $R O A_{i, t}$ as the average return across all other firms in the industry (or the market) except the firm in question. For each firm we require at least six years of data during 1983 through 1992 to run regression [20].

We follow the same step-by-step procedure outlined above with regards to [1] through [8]. We take an average of the unexplained variation in [20] calculated across all firms $j$ in 
industry $i$ and weighted by, $T_{j}$, the number of annual return observations for each firm to obtain

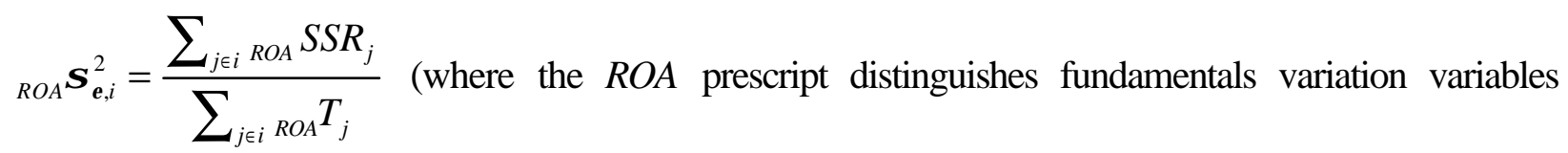
from their stock returns variation counterparts).

As before, we take a logarithm of this to obtain

$$
{ }_{R O A} \Theta_{i}=\ln \left({ }_{R O A} \sigma_{\varepsilon, i}^{2}\right)
$$

A similar procedure yields an estimate of the variation in firm $j$ 's $R O A$ that is associated with market and industry factors, ${ }_{R O A} \sigma_{m, i}^{2}$. Again, a logarithmic transformation gives

$$
{ }_{R O A} \varnothing_{i}=\ln \left({ }_{R O A} \sigma_{m, i}^{2}\right)
$$

Finally, we construct a measure of the relative levels of systematic versus firm-specific $R O A$ variation, denoted

$$
{ }_{R O A} R_{i}^{2}=\frac{R O A}{\sigma_{m, i}^{2}}
$$

Like [7], [23] can be interpreted as if it were the $R^{2}$ of a regression, in that it measures explained variation relative to total variation. A logistic transformation of [23] gives

$$
{ }_{R O A} \Psi_{i}=\ln \left({ }_{R O A} \sigma_{\varepsilon, i}^{2}\right)-\ln \left({ }_{R O A} \sigma_{m, i}^{2}\right),
$$

analogous to $\psi$ in [8].

Panel C of Table 2 contains univariate statistics for all of these control variables, and Table $3 \mathrm{~b}$ presents their simple correlation coefficients with each other. Table $3 \mathrm{c}$ shows that long-term debt, equity financing, and short-term debt are all negatively correlated with size (the logarithm of real property plant and equipment). Long-term debt financing and equity financing are also both positively correlated with net current assets, $\lambda_{i}$ 


\subsection{Regressions}

Table 4 shows our regression results. Because we truncate our dependent variables to lie within the unit interval, we employ two-boundary Tobit regressions. All regressions include 1digit industry dummies to control for industry fixed effects. We find that external financing remains positively correlated with firm-specific information capitalization intensity after controlling for size, market concentration, diversification, spending on intangibles, net current assets, past new long term debt, one-digit industry fixed effects, and fundamentals comovement. $^{7}$

These findings are clearly at odds with the hypothesis that firm-specific stock pricing might be less efficient during times of high intensity firm-specific information capitalization. Indeed, the opposite relationship would appear to hold: stock prices in industries with high intensity firm-specific information capitalization may track firm's fundamentals better, leading to better access to outside financing.

\subsection{Robustness}

In this section, which can be skipped without loss of continuity, we consider variants of the regressions in Table 4 that construct key variables in slightly different ways from those described above, that substitute other plausible control variables for those described above, or that include additional control variables. None of these changes alter our findings qualitatively. By this we mean that, although the magnitudes of some coefficients and standard errors may

\footnotetext{
${ }^{7}$ We also find that industry with higher firm-specific stock price variation tend to use more equity and long-term financing than short-term financing. The correlation of $\left(\sum_{j, t} \Delta L D_{j, t}+\Delta E_{j, t}\right) /\left(\sum_{j, t} \Delta D_{j, t}+\Delta E_{j, t}+\Delta S D_{j, t}\right)$ with $\Theta$ is 0.111 $(p-v a l=0.10)$, and its correlation with $\Psi$ is $0.03(p-v a l=0.24)$. These findings are consistent with more intense firm-specific information capitalization being associated with greater use of equity and bond financing and less use of bank financing.
} 
change, and some control variables may gain or lose statistical significance, the signs and significance patterns of our information capitalization intensity variables, $\Theta_{i}$ and $\varnothing_{i}$ or $\Psi_{i}$, do not change. That is, the relationships between information capitalization intensity and the use of external funds are stable across these specification changes.

\section{The Measurement of External Financing}

Although we believe the dependent variables in Table 4 to be the best approach to gauging use of external funds, we recognize that other approaches are also sensible. In this section, we consider such alternative approaches.

First, by construction, the dependent variables in Table 4 are truncated at zero and one. This is because we are concerned that values outside this range might signify large-scale onetime recapitalizations. We exclude such events because we are interested in typical practice in tapping capital markets. Using broader aggregated external financing measures, like debt plus equity, mitigates this problem to some extent, but does not eliminate it. Truncating at zero and $100 \%$ of capital spending also allows us to interpret our external financing variables as fractions of capital spending, which is a meaningful metric in addressing the questions at hand.

It might be argued that this truncation is nonetheless arbitrary. Clearly, 1993 to 1997 debt issues of forty times capital spending over the same period probably indicate a one-time event, as does a net repurchase of a similar magnitude. However, debt issues of $150 \%$ of capital spending might indicate better access to debt markets than debt issues of $125 \%$ of capital spending. Nonetheless, we are confident that our results are not an artifact of our truncation procedure because Tobit regressions of dependent variables constructed using other cut-offs and OLS regressions on nontruncated dependent variables generate qualitatively identical results. 
Second, in the construction of $\Delta s d$, we also considered "total current liabilities" as a substitute for the sum of current debt and accounts payable. This generates less significant results, presumably because the more inclusive variable contains more noise.

Third, we consider alternative definitions of capital spending, the denominator in our various measures of sources of funds to cover capital spending. One variant is to include merger and acquisition costs in capital spending. This does not change our basic results. Another variant is to augment investment in physical capital by investment in research and development (R\&D) and advertising. When we scale the external financing measures by the sum of capital expenditure, R\&D spending and advertising spending, our results are qualitatively unaffected.

\section{Control Variables}

In this subsection, we return to our list of control variables, and consider reasonable alternatives to those described above. We also consider alternative methods of constructing control variables, and additional control variables that might have been included in Table 4 . We find that these changes do not qualitatively alter our basic findings.

First, the regressions in Table 4 include one-digit industry fixed effects. Using two-digit fixed effects instead generates qualitatively similar results, and the 59 two-digit dummies are mostly insignificant.

Second, movement toward free trade due to NAFTA and the WTO may enhance the ability of industries with a strong comparative advantage to raise outside financing. However, this is probably not a critical omission because adding direct measures of the comparative advantages of US industries preserves our basic results. For example, including industry exports minus imports over industry sales also does not change our findings. Including industry capital 
labor ratios, indirect measures of comparative advantage, also fails to qualitatively alter our results. ${ }^{8}$

Third, we control for industry competitive structure with a sales-based Herfindahl index. Substituting a Herfindahl indexes based on firm assets or employees again leads to qualitatively similar results.

Fourth, we use the natural logarithm of fixed capital to proxy for industry size. We reestimated the value of fixed assets using reported accounting depreciation each year, $D_{j, t}$, rather than assuming a 10\% economic depreciation rate. The resulting recursive formula,

$$
K_{j, t+1}=K_{j, t}-D_{j, t+1}+\frac{\Delta X_{j, t+1}}{\prod_{\tau=0}^{t+1}\left(1+\pi_{\tau}\right)}
$$

generates an alternative panel of firm-level fixed assets. Using this measure throughout, rather than that from [17] does not qualitatively change our findings. Using the logarithms of 1990 to 1992 average "total book assets" or "number of employees" as alternative size measures also does not qualitatively change our result.

It might be argued that industry size is less important in accessing external funds than is firm size. We therefore consider as additional independent variables several measures of average firm size in each industry. These measures are the logarithms of 1990 to 1992 average real assets estimated using [17], average real assets estimated using [25], book assets, real sales, or employees. Adding these variables does not qualitatively change our results.

Fifth, we control for internal liquidity using net current assets as a fraction of total assets. As an alternative liquidity control variable, we use internal cash flow available to finance capital spending in industry $i$,

\footnotetext{
${ }^{8}$ Industry imports and exports are from the NBER-CES Manufacturing Industry Database. These data are available only for manufacturing (SIC codes from 2000 to 3999) industries. Capital-labor ratios are deviations from the economy -wide weighted average.
} 


$$
c_{i}=\frac{\sum_{j \in i, t \in[1990,1992]} \text { income }_{j, t}+\text { depreciation }_{j, t}}{\sum_{j \in i, t \in[1990,1992]} \text { tangible assets }_{j, t}}
$$

where $j$ is an index over firms that are members of industry $i$. The numerator is constructed by summing inflation-adjusted 1990, 1991, and 1992 data for all firms in each industry. The denominator is industry real property, plant and equipment, estimated using the recursive procedure in [17], plus real inventory. Substituting this for the internal liquidity control described in [18] does not qualitatively change our basic results, nor does adding [26] as an additional control. Another version of liquidity measure, past new long-term debt, the 19901992 version of $\Delta l d$, does not change our results either.

Sixth, substituting variants of our basic fundamentals co-movement variables also yields qualitatively similar results. We use [17] to adjust the denominator of ROA for inflation. Constructing ROA entirely from book values generates the same pattern of signs and significance, as does adjusting PP\&E with reported depreciation, as in [25] rather than the depreciation values assumed in [17]. We drop observations where $\left|R O A_{j t}-R O A_{j, t-1}\right|>25 \%$ to avoid spurs in accounting ROA caused not by changes in real fundamentals, but by transitory extraordinary events and tax saving practices. This eliminates 17 firms from our sample. Leaving these observations in does not qualitatively affect our results.

Another straightforward variant is to substitute co-movement in return on equity

$$
R O E_{j}=\frac{\text { income }_{j}+\text { depreciation }_{j}}{\text { net } \text { worth }_{j}}
$$

for co-movement in return on assets in estimating [20]. Constructing this alternative fundamentals co-movement control variable necessitates dropping 4 observations where net worth is negative. Using co-movement in ROE to control for fundamentals co-movement yields results similar to those shown in the tables. Also, both $R O A$ and $R O E$ co-movement can be 
estimated relative to an equal, rather than market value, weighting of the indexes. Weightings based on sales, book assets, or book equity also yield qualitatively similar results to those shown in the tables.

An issue with all the above direct measures of fundamental variation is that while they are based on a long window they are unreliable estimates because changes in firm conditions and the like. Since our purpose is to estimate how similar are firms' fundamentals, we can use a panel variance of $R O A_{j}$ using all firms $j$ in each industry $i$ in 1990 to 1992 as an alternative control variable. This also produces qualitatively similar results. Using a time-series average of cross-sectional variances also yields qualitatively similar results.

Seventh, more rapidly growing industries, such as high-technology sectors, may attract more attention, and hence stocks in those industries may capitalize more information. These industries may also access external capital more often, creating a spurious correlation between information capitalization intensity and external financing. This argument does not appear to generate our results because when we repeat our Table 4 regressions using only the industries with report zero $R \& D$ spending, we obtain results qualitatively similar to those shown in Table 4. It appears that, even in low-tech industries, which presumably have few profitable growth options, greater use of outside financing accompanies higher firm-specific information capitalization intensity. ${ }^{9}$

Eighth, although our focus is on the corporate finance interpretation of stock price variation as more rapidly growing industries, research in asset pricing has clearly demonstrated a linkage between asset returns and systematic risk. Although such effects should be controlled for by including systematic risk, measured by $\varnothing$, and scaling firm-specific risk by systematic 
risk, as in $\Psi$, risk-return effect perhaps deserve more consideration. We need to be fairly certain that our results are not a disguised artifact of a relationship between costs of capital and systematic risk. This does not appear to be so because when, we divide industries into above- and below-median $\Psi$ (firm-specific relative to systematic information capitalization intensity), the two resulting returns distributions are statistically identical, indicating similar 'cost of equity' distributions. For the 1990-1992 data, the Kolmogorov-Smirnov D-statistic for rejecting identical distributions is 0.1064 ( $\mathrm{p}$-value $=0.7446$ ). For the 1993-97 data, D-statistic is 0.2408 (p-value $=0.6242) . \quad$ Furthermore, explicitly including 1990 to 1992 industry-average weighted average costs of capital or 1990 to 1992 unlevered betas as additional controls generates qualitatively similar findings to those shown in Table 4. Adding past equity costs or equity betas as additional control variables also yields qualitatively similar results.

Ninth, Table 4 regresses 1993 to 1997 external financing on 1990 to 1992 information capitalization intensity variables $\Theta, \varnothing$, and $\Psi$. This is done to mitigate endogeneity problems. However, it might be argued that current share price uncertainty should affect current access to external funds. We therefore repeat our regressions using contemporaneous values of the outside financing variables and $\Theta_{i}, \varnothing_{i}$, and $\Psi_{i}$. We first measure both sets of variables across 1990 to 1992, and then measure both across 1993 to 1997 . We find qualitatively similar results to those shown, but with reduced significance for the information capitalization variables in the regressions involving new equity financing.

Tenth, recall that Table 4 uses a cross-section of industry observations. Aggregating to industry-level data avoids estimation problems associated with firm exit and entry lets us pool cross-section and time-series data to construct more reliable estimates for our dependent

\footnotetext{
${ }^{9}$ We can also explore this possibility using marginal and average Tobin's $q$ ratios, variables we develop in section six below. Including either marginal or average $1992 q$ ratios 1992, as an additional control variable leaves our
} 
variables, and reduces error in variables problems due to reporting errors and the like. However, we can run firm-level regressions analogous to the industry-level regressions we report. These regressions include the firm- level version of $\Theta, \varnothing, \Psi,{ }_{R O A} \Theta,{ }_{R O A} \varnothing,{ }_{R O A} \Psi$, diversification, size, spending on intangibles, net current assets, past new long term debt, and three-digit SIC industry dummies. $^{10}$ The results are qualitatively similar to those reported in Table 4.

In summary, our results survive a battery of robustness checks. Although no hypothesis can be proven definitively by such checks, we believe they justify the tentative conclusion that external financing is used more in industries where stocks capitalize firm-specific information more intensively.

\subsection{Discussion}

The focal result in Table 4 is a positive relationship between firm-specific information capitalization intensity and the use of external financing. This relationship is highly statistically significant and highly robust.

The positive relationship between firm-specific information capitalization and external financing is also economically significant. A one standard deviation increase in absolute firmspecific information capitalization intensity, $\Theta=\ln \left(\sigma_{\varepsilon}^{2}\right)$, raises new debt over capital spending by $0.105 \times 0.859$ or 0.090 , roughly $22.3 \%$ of 0.405 , the average of that ratio. Analogous calculations show that a one standard deviation increase in $\Theta$ raises the use of external equity by $8.9 \%$, and short-term external funds by $14.1 \%$, and total external funds by $4.8 \%$. A one standard deviation increase in relative firm-specific information capitalization intensity, $\Psi$, raises the use

results qualitatively unchanged.

${ }^{10}$ The inclusion of 3-digit SIC industry dummies makes it unnecessary to control for industry market structure as captured by the Herfindahl index. 
of external debt by $14.6 \%$, external equity by $6.6 \%$, short-term external funds by $17.9 \%$, and total external financing by $4.0 \%$.

Although other explanations may be possible, these findings are consistent with higher firm-specific information capitalization intensity indicating stock prices that track fundamentals more closely, rather than more loosely, and so with reduced costs of external funds of the sort described by Myers and Majluf (1984).

\section{Firm-specific Information Capitalization and the Marginal Value of Capital}

If higher firm-specific information capitalization intensity is indeed associated with stock prices tracking fundamental values more closely, this should affect corporate decision-making. In particular, a more efficient stock market should cause a more efficient allocation of capital across and within firms. More meaningful stock prices should render managerial incompetence and diversions of funds more obvious to shareholders and to the board, and therefore presumably easier to correct. Moreover, more meaningful stock prices should help competent and honest managers understand their firms' economic environments better, and thereby make better capital spending decisions. The result should be a condition closer to the textbook dea that all positive NPV projects be undertaken and all negative NPV projects be avoided.

In this section, we relate ex-post NPVs of capital investment to intensity in firm-specific information capitalization. To measure the ex-post marginal value of investment, we estimate marginal Tobin's $q$ ratios for each industry using our 1993 to 1997 sample. We find that industries characterized by higher firm-specific information capitalization intensity have marginal $q$ ratios closer to one. 


\subsection{The Quality of Capital Budgeting Decisions}

Capital budgeting is the process by which firms purchase various combinations of capital goods to generate future cash flows for shareholders. Hayek $(1941,1945)$ argues that this process is driven by the gathering and processing of information about shifting prices and technological constraints, and points out that successful capital budgeting policies capture such fleeting economic profits (quasirents) as these shifts create. The present value of the quasirents captured by a capital investment project is referred to as the project's net present value (NPV), and this is the amount by which the project increases the firm's value in an efficient stock market. Value-maximizing firms therefore should fund all value-increasing (positive NPV) projects, but no value-decreasing (negative NPV) projects. Hayek postulates that successful capital budgeting is harder under some circumstances than others, and this postulate is the subject of this section.

To gauge the success of capital budgeting policies, we estimate firm's marginal $q$ ratios. Firm $j$ 's period $t$ marginal $q$ ratio, which we denote $\dot{q}_{j, t}$, is the amount by which the firm's value, $V_{j, t}$, rises per unit increase in its stock of capital goods, $A_{j, t}$. Thus,

$$
\dot{q}_{j, t} \equiv \frac{d V_{j, t}}{d A_{j, t}}
$$

In a perfectly efficient market, a firm's marginal $q$ is the present value of the future cash flows its marginal capital investment would generate divided by the marginal cost of that investment. In the terminology of standard capital budgeting problems, a firm's marginal $q$ ratio is one plus the expected profitability index of its marginal investment project. That is, in a perfectly efficient stock market, a firm's marginal $q$ is one plus the net present value (NPV) of its marginal capital budgeting project divided by the setup cost of that project. Thus, 


$$
\dot{q}_{j, t} \cong \frac{1}{C_{j, t}} E\left(\sum_{s=t+1}^{\infty} \frac{c f_{j, s}}{\left(1+r_{j, t}\right)^{s-t+1}}\right)=1+\frac{N P V_{j, t}}{C_{j, t}}
$$

where $C_{j, t}$ is the set up cost of firm $j$ 's marginal unexpected capital project in period $t, c f_{j, s}$ is the cash flow shareholders generated by that project in period $s>t$, and $r_{j, t}$ is firm $j$ 's discount rate as of period $t$.

Non-value-maximizing capital budgeting can lead to either over-investment or underinvestment (or both). Over-investment occurs when a firm undertakes a value-destroying (negative NPV) project. Undertaking such a project leaves the firm with a marginal $q$ below one. Under-investment occurs if a firm passes up value creating (positive NPV) projects. Halting capital expenditures when positive NPV projects remain unexploited leaves the firm with a marginal $q$ above one. ${ }^{11}$

The purpose of this section is to test for a relationship between firm-specific information capitalization and the deviation of marginal $q$ from its optimal value, which we presume for the time being to be one.

\subsection{Marginal $q$ Estimation Procedure}

To construct marginal $q$ estimates, we regress changes in a firm's market value on changes in the value of its capital assets from 1993 to 1997 for firms in each of our 3-digit industries using a random firm and time effects model, controlling for dividend policy, depreciation, and expected capital gains. The resulting regression coefficient on the change in capital asset value is an estimate of the average firm-level marginal $q$ in that 3-digit industry.

\footnotetext{
11 If pretax returns are used, taxes cause the threshold level of marginal $q$ separating under-investment from overinvestment to differ from one. We deal with this explicitly issue below..
} 
The remainder of this section provides a detailed description of our procedure for estimating marginal $q$ ratios. A first-pass approach to estimating marginal $q$ ratios is to run the regression

$$
V_{j t}-V_{j, t-1}=b_{j}\left(A_{j t}-A_{j, t-1}\right)+\mathbf{c}_{j} \cdot \mathbf{z}_{j, t}+u_{j, t}
$$

where $V_{j, t}$ is the value of firm $j$ at time $t, A_{j, t}$ its stock of capital goods, $\mathbf{z}_{j, t}$ a vector of control variables (that may include a constant), and $u_{j, t}$ an estimation error. The coefficient $b_{j}$ is then an estimate of $\dot{q}$, as defined in [28].

This procedure is not satisfactory because some future capital spending is already expected by investors, and is therefore already capitalized into today's share price. However, a regression of the form of [30] can still be used to estimate marginal $q$. To see this, consider marginal $q$ as the unexpected change in firm value during period $t$ divided by the unexpected increase in capital goods during that period.

$$
\dot{q}_{j}=\frac{V_{j, t}-E_{t-1} V_{j, t}}{\left(A_{j, t}-E_{t-1} A_{j, t}\right)}=\frac{V_{j, t}-V_{j, t-1}\left(1+r_{j, t}-d_{j, t}\right)}{A_{j, t}-A_{j, t-1}\left(1+g_{j, t}-\delta_{j, t}\right)}
$$

where $r_{j, t}$ is the expected return from owning the firm, $d_{j, t}$ its expected tax-adjusted dividend rate (including share repurchases and implicit takeover premiums), $g_{j, t}$ the expected rate of spending on capital goods, and $\delta_{j, t}$ the expected depreciation rate on those capital goods.

Rewrite this, normalizing by $A_{j, t-1}$, to obtain

$$
V_{j, t}-V_{j, t-1}=\dot{q}_{j}\left[A_{j, t}-A_{j, t-1}\left(1+g_{j, t}-\delta_{j, t}\right)\right]+V_{j, t-1}\left(r_{j, t}-d_{j, t}\right)
$$

or

$$
\frac{V_{j, t}-V_{j, t-1}}{A_{j, t-1}}=-\dot{q}_{j}\left(g_{j}-\delta_{j}\right)+\dot{q}_{j} \frac{A_{j, t}-A_{j, t-1}}{A_{j, t-1}}-\xi_{j} \frac{d i v_{j, t-1}}{A_{j, t-1}}+r_{j} \frac{V_{j, t-1}}{A_{j, t-1}}
$$


where $d i v_{j, t}$ is dollar dividend payment. ${ }^{12}$

Note that [32] is precisely the regression described by [30] - but with a constant and with lagged dividend yield and lagged average $q$, or $V_{t-1} / A_{t-1}$, included as control variables. The constant can be cautiously interpreted as an estimate of $-\dot{q}_{j}\left(g_{j}-\delta_{j}\right)$, where the $j$ subscript indicates a time series average. The coefficients of the lagged dividend yield and lagged average $q$ can be loosely interpreted as a dividend tax correction factor and an estimate of the firm's discount rate.

We estimate $V_{j, t}$ and $A_{j, t}$ as

$$
\begin{aligned}
& V_{j, t}=P_{t}\left(C S_{j, t}+P S_{j, t}+L T D_{j, t}+S D_{j, t}-S T A_{j, t}\right) \\
& A_{j, t} \equiv K_{j, t}+I N V_{j, t}
\end{aligned}
$$

where

$$
\begin{aligned}
C S_{j, t}= & \text { the year t calendar year-end market value of the outstanding common shares of } \\
& \text { firm } j . \\
P S_{j, t}= & \text { the estimated market value of preferred shares (the preferred dividends paid over } \\
& \text { the Moody's baa preferred dividend yield). } \\
L T D_{j, t}= & \text { estimated market value of long-term debt, calculated recursively from historical } \\
& \text { changes in book values and assuming all debt to be } 15 \text { year bonds issued at par. } \\
S D_{j, t}= & \text { book value of short-term debt. } \\
S T A_{j, t}= & \text { book value of short-term assets. } \\
P_{t}= & \text { inflation adjustment using the GDP deflator. } \\
K_{j, t}= & \text { estimated market value of firm } j \text { 's property, plant and equipment, as defined in } \\
& \text { equation [17]. } \\
I N V= & \text { estimated market value of inventories. This is taken as equal to the book value for } \\
& \text { firms using FIFO accounting. For firms using LIFO accounting, a recursive }
\end{aligned}
$$

12 This relationship can also be derived as an Euler equation resulting from the firm's intertemporal value maximization problem. 
process is used to estimate the age structure of inventories and inventories of each age are adjusted for inflation using the GDP deflator.

We partition the 1993 to 1997 sample into three-digit industry subsamples of firms. For each subsample, we regress

$$
\frac{\Delta V_{j, t}^{i}}{A_{j, t-1}^{i}}=\alpha^{i}+\beta_{0}^{i} \frac{\Delta A_{j, t}^{i}}{A_{j, t-1}^{i}}+\beta_{1}^{i} \frac{V_{j, t-1}^{i}}{A_{j, t-1}^{i}}+\beta_{2}^{i} \frac{d i v_{j, t-1}^{i}}{A_{j, t-1}^{i}}+u_{j, t}^{i}
$$

to obtain a marginal $q$ estimate, $\dot{q}_{i} \cong \beta_{0}^{i}$, for that industry ( $d i v_{j, t-1}^{i}$ is defined as dividends for common shares plus repurchases of common shares). Error terms are assumed to satisfy the following conditions: $u_{j, t}^{i}$ has zero mean, $\operatorname{cov}\left(u_{j, t}^{i}, u_{j, s}^{i}\right) \neq 0 \forall t$ and $s$; and $\operatorname{cov}\left(u_{j, t}^{i}, u_{k, t}^{i}\right) \neq 0 \forall j$ and $k$. Equation [38] is estimated in a firm-time random effects model. All variables are scaled by $A_{j, t-1}^{i}$ to mitigate heteroskedasticity problems.

The average estimated values of the coefficients $\beta_{1}^{i}$ and $\beta_{2}^{i}$ are broadly consistent with their interpretations in [32]. The average estimated coefficient on lagged average $q$ (i.e., $\beta_{1}^{i}$ ) is 0.093, implying an average discount rate of $9.32 \%$. The average estimated coefficient $\beta_{2}^{i}$ on the pretax dividend rate is -0.869 , and is insignificantly different from negative one in 56 out of 214 industries. The average intercept, $\alpha^{i}=-\dot{q}_{j}\left(g_{j, t}-\delta_{j, t}\right)$, is -0.051 , and is not significantly different from zero in 98 of 214 industries.

Additional collaborative evidence adds credence to our marginal $q$ estimates. The regression coefficient $\alpha^{i}=-\dot{q}_{j}\left(g_{j, t}-\delta_{j, t}\right)$ is indeed negative and significantly correlated with growth in physical capital. Also, $\beta_{1}^{i}$ is indeed highly significantly positively correlated with estimated weighted average costs of capital. 


\subsection{Marginal $q$ as the Basis for Measures of Capital Budgeting Decision Quality}

We are interested in whether the intensity of firm-specific information capitalization is associated with the distance of marginal $q$ 's from its optimal value, which we assume to be one for now. If more firm-specific information capitalization is associated with stock prices being farther from fundamentals, marginal $q$ should be further to one in industries where firm-specific information capitalization intensity is larger.

We measure the distance between $\dot{q}$ and one as either $(\dot{q}-1)^{2}$, the square of marginal $q$ minus one, or as $|\dot{q}-1|$, the absolute value of marginal $q$ minus one. The former metric places a heavier weighting of extreme values of marginal $q$. Summary statistics of $\dot{q},(\dot{q}-1)^{2}$ and $|\dot{q}-1|$ are presented in panel $\mathrm{D}$ of Table 2 .

\subsection{Simple Correlations}

Table 5 presents simple correlation coefficients between the marginal $q$ based investment allocation measures $(\dot{q}-1)^{2}$ and $|\dot{q}-1|$ and our other variables. Marginal $q$ tends to be closer to one in industries where stock returns exhibit greater firm-specific variation, $\Theta_{\mathrm{i}}$. Marginal $q$ is also closer to one in industries that display higher relative firm-specific information capitalization $\Psi_{\mathrm{i}}$. Marginal $q$ is not, however, closer to one as systematic variation, $\varnothing_{\mathrm{i}}$ rises. However, $\dot{q}$ per se is uncorrelated with all three information capitalization intensity measures $\Theta_{\mathrm{i}}, \varnothing_{\mathrm{i}}$, and $\Psi_{\mathrm{i}}$.

Marginal $q$ is closer to one in industries that make more extensive use of external financing. This is consistent with the positive relationship, proposed by Myers and Majluf (1984) between the use of external funds and the prevalence of efficient capital spending, and so 
lends further credibility to our marginal $q$ estimates. Marginal $q$ is also related to industry size and liquidity, but these correlations are not robust to the distance metric used.

Moreover, partitioning the sample into industries with marginal $q$ above and below one also strengthens the credibility of our marginal $q$ estimates. In the $\dot{q}<1$ subsample, marginal $q$ rises as more outside financing is used to finance capital expenditure, consistent with value destroying investments being funded from excess internal free cash flow, as proposed by Jensen (1986). In contrast, in the $\dot{q}>1$ subsample, net current assets over total asset is negatively and significantly correlated with marginal $q$, consistent with liquidity constraints causing capital rationing.

\section{$5.5 \quad$ Regressions}

Table 6 present regressions of the distance of marginal $q$ from one on our stock price variation variables and the control variables discussed above. In the regression, we include all the control variables in Table 4. In particular, we control for one-digit SIC code industry, firm diversification, market structure, industry size, liquidity, leverage, and spending on intangibles. The justifications for these control variables parallel those in the external financing regression. More diversification, less leverage and more market concentration may mean less sharp monitoring and thus more room for managerial agency behavior. It turns out that the only statistically significant control variable is the Herfindahl index which attracts a positive coefficient, indicating that industries dominated by a few firms tend to have less optimal investment decisions.

The central result in table 6 is that higher firm-specific information capitalization intensity $\Theta_{\mathrm{i}}$ is statistically significantly associated with marginal $q$ being closer to one, as is relative firm-specific information capitalization, $\Psi_{\mathrm{i}}$. This finding is consistent with our 
conjecture that more intense capitalization of greater firm-specific information capitalization intensity is associated with more efficient capital spending decisions.

\subsection{Robustness}

In this section, which can be skipped without loss of continuity, we show that the central results in Table 6 are highly robust to reasonable specification changes and over various subsamples.

The results in this section survive the robustness tests described in connection with the external financing regressions of Table 4 that are relevant to the marginal $q$ regressions. Qualitatively similar results ensue using two-digit industry fixed effects. The same is true when we add industry export minus imports over industry sales, capital labor ratios, average firm size, past stock return, or past equity beta as additional controls. Using alternative measures of market structure, industry size, liquidity, and fundamentals co-movement also generates qualitatively similar results. Qualitatively similar results also ensue if we restrict the analysis to industries reporting no R\&D, if we separate above and below median $\Psi$ industries, and if we divide our sample into positive and negative industry returns in 1990-1992. Using contemporaneous marginal $q$ and information capitalization variables also generates qualitatively similar results, though the justification for using contemporaneous variables is weaker here, as the consequences of capital budgeting decisions plausibly last longer than the ability to access external funds.

Note however, that using firm-level data rather than industry-level data is not an option in this section of the paper. Using firm level data provides us with only a handful of observations for each estimation of regression [38]. Aggregating to industry-level data is critical here because it allows us to use panel data to estimate [38], and hence marginal $q$, reliably. 
Our marginal $q$ results also survive an additional set of robustness checks, which we now describe.

First, it is not clear that the threshold value of marginal $q$ should be one. Tax and other effects can lead to a threshold value of marginal $q$ lower than one. Investors' return from plowing back a dollar of after-tax income into capital investment is $\dot{q}(1+D)\left(1-T_{C G}\right)$ where $D$ is the value of the depreciation tax shield generated and $T_{C G}$ is the capital gains tax the investors pay upon selling the stock. For capital investment to make sense, this must be larger than the value to the investor of paying a dollar dividend or buying back a dollar's worth of outstanding stock. The value of the former is $\left(1-T_{D I V}\right)$ where $\mathrm{T}_{D I V}$ is the personal tax on dividends. The value of the latter is $\left(1-T_{C G}\right)$. This comparison is complicated by issues such as the timing of capital gains realization, depreciation tax rules, and the fact that some investors are tax free while other face a variety of marginal rates. Reasonable figures for the $1990 \mathrm{~s}$ are $T_{D I V}$ in the $33 \%$ to $39.6 \%$ range, $T_{C G}$ equal to $28 \%$, the present value of the depreciation tax shield equal to $23 \%$ of the value of capital invested, and repurchases equal to $20 \%$ of disbursement (Fama and French, 2000). These imply a threshold marginal $q$ in the general neighborhood of 0.8 . We therefore reestimate Table 6 using threshold values ranging from 0.75 to 1.00 . A threshold of 0.86 generates the highest significance level; however, all these threshold values generate qualitatively similar results to those shown.

Moreover, since tax effects differ across industries, the tax-adjusted threshold marginal $q$ might be industry specific. However, the inclusion of one-digit industry dummies may capture such effects to some extent, and our results are qualitatively similar if we include two-digit industry dummies, and if we exclude the industry dummies altogether.

Second, we can check on robustness of Table 6 by partitioning the sample into high and low marginal $q$ subsamples. We begin by using one as the division point between these. For the 
marginal $q<1$ sample (162 observations), we find strong results in both regression and simple correlation analyses: higher $\Theta$ and $\Psi$ are significantly linked to higher marginal $q$. For the marginal $q>1$ sample (52 observations), our focal variables $(\Theta$ and $\Psi$ ) are insignificant but with the correct sign: higher $\Theta$ and $\Psi$ are linked with lower marginal $q$. We suspect that the insignificance may be due to the smaller sample size. When we repeat the analyses using marginal $q=0.8$ as the dividing line between the high and low marginal $q$ subsamples, we find significant relationships in both subsamples consistent with those shown in the tables. Higher $\Theta$ and $\Psi$ are linked with lower marginal $q$ in the marginal $q>0.8$ subsample (98 observations), and with higher marginal $q$ in the marginal $q<0.8$ subsample (116 observations).

Third, optimal investment policies imply that marginal $q$ should be close to one, or to a tax-adjusted threshold value, which we estimate to be slightly below one. The regressions in Table 6 should not work if we use marginal $q$ itself as the dependent variable. When we run $\dot{q}$ itself on the independent variables in Table 6 across the full sample of industries, we obtain insignificant coefficients on the firm-specific information capitalization intensity variables.

Fourth, investment should perhaps include more than just spending on property, plant and equipment. Spending on intangible assets, such R\&D and advertising, is also arguably a form of investment despite the fact that generally accepted accounting principles do not recognize it as such. We can modify [38] to incorporate spending on intangibles in the estimation of $\dot{q}$. Doing so does not change our results qualitatively.

Fifth, dividend payments (including stock repurchases) are used in estimating [38]. In some industries, only a few firms pay dividends or repurchase stock consistently. We therefore constrain $\beta_{2}^{i}$ to be zero in industries with less than $10 \%$ of firms paying dividends or 
repurchasing stock and re-estimate our marginal $q$ s. These alternate marginal $q$ s generate results qualitatively similar to those shown in Table 6.

Sixth, studies of corporate investment often consider average Tobin's $q$, rather than marginal $q$, since average $q$ measures total, rather than marginal, value added. Average $q$ is the total market value of the firm, $V_{j, t}$, over the total replacement cost of all the firm's assets, $A_{j, t}$. Thus,

$$
\bar{q}_{j, t} \equiv \frac{V_{j, t}}{A_{j, t}},
$$

where $V_{j, t}$ and $A_{j, t}$ are as explained in [33].

As a firm invests in ever more marginally value-increasing projects, its marginal $q$ falls to one. Its average $q$, however, need not fall to one, for the firm's average $q$ is investors' expected present value of cash flows from its marginal and inframarginal capital investments; all scaled by the sum of the replacement costs of the assets associated with those investments. Thus, all else equal and in the absence of liquidity constraints, a high average $q$ ratio signifies a history of ex post value-creating investments. If higher intensity firm-specific information capitalization leads to better investment decisions, a positive relationship between average $q$ and firm-specific information capitalization intensity should be evident.

To estimate an industry's average $q$, we sum the market values of all firms in that industry, and divide this by the sum of all their replacement costs. The market value and the replacement costs of tangible assets are as described in [33]. We then take an average for each industry from 1993 through 1997. Average $q$ is negatively correlated with marginal $q$ 's deviation from 1 , and uncorrelated with marginal $q$ itself, and positively significantly related to all five measures of the use of external financing. 
Both simple correlation coefficients and regressions of average $q$ on the independent variables in Table 6 confirm that higher average $q$ is statistically significantly associated with higher absolute and relative firm-specific information capitalization intensities, $\Theta_{i}$ and $\Psi_{i}$, but uncorrelated with systematic information capitalization intensity, $\varnothing_{i}$.

These results survive the above mentioned robustness checks for Table 6. Similar results follow from both industry- and firm-level regressions. Using value to sales ratios instead of average $q$ also generates similar results, as does using contemporaneous dependent and independent variables rather than lagging the latter. Also, separate regressions on high and low average $q$ industries generate positive coefficients on firm-specific information capitalization intensity in both subsamples.

Finally, liquidity constraints can affect $q$ ratio results when a firm's cost of capital is discontinuous. This occurs, for example, when a firm's last inframarginal capital spending project exhausts its internal capital budget and its marginal project therefore requires switching to higher cost external funds. This allows the marginal project to have a negative NPV even though the last (observed) inframarginal project had a positive NPV. Thus, a low marginal $q$ indicates overinvestment and suggests problems in capital budgeting, but a high marginal $q$ can indicate either underinvestment due to poor capital budgeting or a binding liquidity constraint.

Because Table 4 shows industries characterized by high intensity firm-specific information capitalization to access external funds more, we believe liquidity constraints unlikely to underlie the negative relationship we observe between marginal $q$ and firm-specific information capitalization. To further investigate this issue, we re-estimate Table 6 for the $\dot{q}>$ 0.8 subsample of industries, but including as controls all three of our liquidity measures: net current assets over total assets, cash flow over total assets, and past external financing activity. 
The negative relationship between marginal $q$ and firm-specific information capitalization intensity remains significant.

In conclusion, our results survive numerous robustness checks. While we acknowledge that further analysis may overturn our results, we regard them as persuasive evidence that more intensive firm-specific information capitalization into stock prices is associated with capital budgeting policies more consistent with more value maximization.

\subsection{Discussion}

The results in this section indicate that higher firm-specific information capitalization intensity is associated with marginal $q$ ratios closer to what we believe to be optimal values. This can be interpreted as indicating a positive relationship between the intensity of firm-specific information capitalization and the economic efficiency of capital spending decisions. This relationship is highly statistically significant and highly robust.

The positive relationship between firm-specific information capitalization and the proximity to one of the marginal value of a unit of capital spending is also economically significant. In regression 6.2, a one standard deviation increase in absolute firm-specific information capitalization intensity, $\Theta$, reduces $(\dot{q}-1)^{2}$ by $0.450 \times 0.859$ or 0.387 , roughly $66 \%$ of the mean squared distance of marginal $q$ from one across industries. Analogous calculations show that a one standard deviation increase in $\Theta$ lowers the absolute distance of marginal $q$ from one by $17 \%$ of its cross-industry mean. A one standard deviation increase in relative firmspecific information capitalization intensity, $\Psi$, reduces the mean squared and absolute distances of marginal $q$ from one by $40 \%$ and $9 \%$ respectively. 
These findings are once again consistent with higher firm-specific information capitalization intensity indicating that stock prices that track fundamentals more closely, rather than more loosely, and so with reduced malinvestment of the sort described by Hayek (1941).

\section{Interpreting Differences in Firm-specific Information Capitalization Intensity}

We have shown that, after controlling for both firm-specific and systematic fundamentals variation and other factors, higher firm-specific stock return variation is associated with greater use of external financing and reduced malinvestment. We propose that greater firm-specific stock returns variation indicates that stock prices track firm fundamentals more closely. This closer proximity of stock prices to fundamental values then explains the observed increased use of external funds and higher quality capital budgeting decisions.

This interpretation of our results begs the question of why stock prices should track fundamentals more closely in some industries than others, even though all stocks in the US market are traded in essentially the same legal, regulatory and institutional environment. To propose an answer to this question, we must examine the process by which new information enters share prices.

\section{Limits to Risk Arbitrage}

Black (1986), Shleifer and Vishny (1997) and others stress the importance of risk arbitrageurs in keeping stock prices close to their fundamental values. Risk arbitrageurs gather information about firms, industries, and the economy and process this information to ascertain 
profitable trading strategies. Roll (1988) and French and Roll (1986) conclude that firm-specific variation is mostly due to risk arbitrage by investors with private information.

Shleifer and Vishny (1997) show that risk-averse risk arbitrageurs limit their trading on private information under plausible assumptions. Shleifer (2000, chapter 4) argues that this is important in actual markets because arbitrageurs' past performance affects their access to capital, and describes how Long Term Capital Management, a hedge fund, failed when its backers grew impatient with continuing losses on an economically sensible arbitrage position that unexpectedly widened, rather than closed, over time. For these and other reasons, Shleifer and Vishny (1997) and Shleifer (2000) argue that share prices can diverge from fundamentals for prolonged periods.

This suggests that differences in the intensity of firm-specific information capitalization may reflect, at least in part, differences in the limits to risk arbitrage across industries. Firmspecific information may be costlier to gather and process or less profitable to trade on in some industries than in others. If so, firm-specific risk arbitrageurs might be less active in some industries than others.

\section{Possible Implications of Limited Arbitrage}

Whether or not limited risk arbitrage could generate the results we find depends on details about the information flow into stock prices that are, at present, unknown. We advance three incomplete descriptions of how the process of information capitalization might occur under severely limited risk arbitrage.

One possibility is that less active informed trading might cause a steadily increasing uncapitalized "build up" of information about changing firm-specific fundamentals. Presumably, large discrete jumps in the share price would occur when the discrepancy between the market 
price and arbitrageurs' estimate of the fundamental value diverged sufficiently to justify arbitrage. Observing low firm-specific returns variation over a fixed short window, we might see few discrete jumps. Low firm-specific returns variation might thus indicate susceptibility to this information 'build up and discharge' pattern. Such a pattern clearly makes share prices less informative, and so might raise the costs of external funds and allow more malinvestment. A positive relationship between our firm-specific information capitalization intensity measures and both the use of external funds and the quality, evaluated ex-post, of corporate investment decisions would thus follow.

An alternative possibility is that old information may grow stale, and that an absence of informed trading might not cause an uncapitalized information build-up. Such 'depreciation' in the value of private information would mean that the gap between true value and market value does not grow to a very large gap to eventually attract arbitrage and thus convergence of the two values. This would mean that some firm-specific events would pass without ever being capitalized into share prices.

In a large enough sample, or over a long enough window, cross-industry differences in our firm-specific information capitalization intensity measures should disappear if they are due to 'information build up and discharge' patterns in some industries. We therefore increased the length of the time period over which we estimate our firm-specific information capitalization intensity variables. We find that differences across industries in the magnitude of firm-specific returns variation are lower when we use a longer estimation period. Also, as we expand the window size, the statistical significance of the firm-specific information capitalization variables in the regressions of Tables 4 and 6 fall, though their signs do not change. A ten-year window is sufficient to render all their coefficients statistically insignificant. 
A third possibility arises from theories of noise trader risk. De Long et al. (1986) stress that increased systematic noise trading may reduce the profitability of informed all risk arbitrage, and thereby impede the capitalization of information into stock prices. This is because such noise trading adds market-wide variation to stock returns, and this increases risk-averse informed traders' costs of capital and causes them to take smaller positions. This reduction in informed risk arbitrage, in turn, allows noise trading to cause an even larger increase in market-wide variation, ad infinitum. Thus, in industries where informed arbitrage is more limited, market wide returns variation should be elevated relative to market wide fundamentals variation. This would reduce the magnitude of firm-specific returns variation measured relative to systematic returns variation, and might also reduce firm-specific returns variation per se. However, this interpretation would seem inconsistent with the usual insignificance of systematic variation $\varnothing_{i}$; and with firm-specific relative to systematic variation, $\Psi_{i}$, not working as well as pure firmspecific variation, $\Theta_{i}$, in many of the above regressions. Nonetheless, our incomplete understanding of the real importance and nature of noise trading prevents a categorical rejection of this hypothesis at present.

Any or all three of these hypotheses might underlie our findings that increased firmspecific information capitalization intensity is associated with greater use of external funds and with reduced malinvestment problems. We recognize that extensive further empirical investigation is needed to fully investigate these alternative hypotheses. Moreover, we recognize that the above list of hypotheses may well be incomplete, and invite other explanations of our empirical findings. 


\section{Conclusions}

We speculate that greater firm-specific stock returns variation reflects the capitalization of firm-specific information into stock prices, and thus indicates more active risk arbitrage trading and hence more efficiently set share prices. We find that such increased firm-specific information capitalization intensity is linked to real investment decisions through at least two general channels.

First, more firm-specific information in stock prices can alleviate the Myers and Majluf (1984) lemons problems associated with accessing external funds, and thereby lower the cost of external capital. Consistent with this, we find that industries exhibiting higher firm-specific stock returns variation to be significantly make greater use of external financing.

Second, finer firm-specific information in stock prices might mitigate malinvestment problems by mitigating these same lemons problems, by increasing corporate transparency, and by providing boards and managers more meaningful feedback. Such feedback plausibly reduces malinvestment problems, or (if ignored) invites the market for corporate control to reduce them. Consistent with these explanations, we find marginal $q$ ratios closer to one in industries with greater firm-specific stock returns variation.

Tobin (1982) argues that the most important consequence of stock market efficiency is its implication of economically efficient firm-level capital allocation, which he dubs the "functional form of the efficient markets hypothesis". We propose that firm-specific stock returns variation, after controlling for firm-specific fundamentals variation and other factors, is positively correlated with firm-specific functional-form efficiency. We suggest that U.S. stock prices are more functionally efficient for some industries than for others, and that this has real economic effects. Although we believe this interpretation of our findings to be sound, we recognize that this work is preliminary and welcome other explanations. 


\section{Refere nces}

Amihud, Yakov and Baruch Lev, 1981, "Risk Reductions as a Managerial Motive for Conglomerate Mergers", Bell Journal of Economics, 12, 605-617.

Black, Fisher, 1986, "Noise”, Journal of Finance, 41:3, 529-543.

Diamond, Douglas, 1993, "Seniority and Maturity of Debt Contracts", Journal of Financial Economics 33, 341-368.

De Long, J. Bradford, Andrei Shleifer, Lawrence Summers and Robert J. H. Waldmann, 1990, “Noise Trader Risk in Financial Markets”, Journal of Political Economy 98:4, 703-738.

Fama, Eugene F. and Kenneth French, 2000, "Disappearing Dividends: Changing Firm Characteristics or Lower Propensity to Pay?", Journal of Financial Economics, forthcoming.

French, Kenneth R. and Richard Roll, 1986, "Stock Return Variances: the Arrival of Information and the Reaction of Traders", Journal of Financial Economics 17:1, 5-26.

Grossman, Sanford, 1976, "On the Efficiency of Competitive Stock Markets Where Traders Have Diverse Information", Journal of Finance 31:2, 573-585.

Hayek, Friedrich A., 1941, The Pure Theory of Capital. Chicago: U. of Chicago Press.

Hayek, Friedrich A., 1945, "The Use of Knowledge in Society", American Economic Review $35: 4,519-30$.

Holmström, Bengt and Jean Tirole, 1993, "Market Liquidity and Performance Monitoring", Journal of Political Economy 101:4, 678-709.

Jensen, M., 1986, "Agency Costs of Free Cash Flows, Corporate Finance and Takeovers", American Economic Review 76, 323-329. 
King, Robert G. and Ross Levine, 1993, "Finance and Growth: Schumpeter Might Be Right", Quarterly Journal of Economics 108:3, 717-737.

Khorana, Ajay and March Zenner, 1998, "Executive Compensation of Large Acquirers in the 1980s", Journal of Corporate Finance, 4:3, 209-240.

La Porta, Rafael, Florencio Lopez de-Silanes, Andrei Shleifer and Robert W. Vishny, 1997, “Legal Determinants of External Finance”, Journal of Finance 52:3, 1131-1146.

Levine, Ross, 1997, "Financial Development and Economic Growth: Views and Agenda", Journal of Economic Literature, 35, 688-726.

Lewellan, William G. 1971, “A Pure Financial Rationale for the Conglomerate Merger" Journal of Finance, 26:2 521-545.

MacKinley, Craig A, 1997, "Event Studies in Economic and Finance", Journal of Economic Literature, 35:1, 13-39.

Mason, Scott P. and Robert C. Merton, 1985, "The Role of Contingent Claims Analysis in Corporate Finance", E. I. Altman and M. G. Subramanyan, eds. Recent Advances in Corporate Finance. Richard D. Irwin, Inc. Homewood, IL.

Matsusaka, John G. and Vikram Nanda, 1994, "Internal Capital Markets and Corporate Refocusing", working paper.

May, Don O., 1995, “Do Managerial Motives Influence Firm Risk Reduction Strategies?”, Journal of Finance 50:4, 1291-1308.

Morck, Randall, Andrei Shleifer and Robert W. Vishny 1990, “Do Managerial Objectives Drive Bad Acquisitions?", Journal of Finance 45:1, 31-48.

Morck, Randall, Bernard Yeung and Wayne Yu, 2000, “The Information Content of Stock Markets: Why Do Emerging Markets Have Synchronous Stock Price Movements?", Journal of Financial Economics, forthcoming. 
Myers, Stewart C. and Nicholas S. Majluf, 1984, "Corporate Financing and Investment Decisions When Firms Have Information That Investors Do Not Have", Journal of Financial Economics 13:2, 187-222.

Petersen, Mitchell A. and Raghuram G. Rajan, 1994, "The Benefits of Lending Relationships: Evidence from Small Business Data”, Journal of Finance 49:1, 3-38.

Pontiff, Jeffrey, 1996, "Costly Arbitrage: Evidence from Closed-End Funds”, Quarterly Journal of Economics 111:4, 1135-51.

Rajan, Raghuram, Henri Servaes and Luigi Zingales. 1998. The Cost of Diversity: The Diversification Discount and Inefficient Investment. National Bureau of economic Research working paper 6368. Forthcoming, Journal of Finance.

Roll, Richard, 1988, R², Journal of Finance 43:2, 541-566.

Ross, Stephen, A., R. W. Westerfield, and B. D. Jordan, 1993, Fundamentals of Corporate Finance, Irwin Press, $2^{\text {nd }}$ edition.

Schumpeter, Joseph A., 1950, Capitalism, Socialism and Democracy, 3rd ed. New York: Harper. Scharfstein, David S. and Jeremy C. Stein, 1997, “The Dark Side of Internal Capital Markets: Divisional Rent-Seeking and Inefficient Investment”, NBER Working Paper No. W5969.

Shleifer, Andrei and Robert W. Vishny, 1997, "The Limits of Arbitrage", Journal of Finance $52: 1,35-55$.

Stein, Jeremy C., 1997, "Internal Capital Markets and the Competition for Corporate Resources", Journal of Finance 52:1, 111-33.

Subrahmanyam, Avanidhar and Sherifan Titman. 1999, "The Going Public Decision and the Development of Financial Markets”, Journal of Finance 54:3, 1043-1082.

Theil, Henri, 1971, Principles of Econometrics, Wiley.

Tobin, James, 1982, “On the Efficiency of the Financial System”, Lloyd's Banking Review, July. 
Wurgler, Jeffrey, 2000, "Financial Markets and the Allocation of Capital", Journal of Financial Economics, 58:1 pp 187-214. 


\section{Table 1}

\section{Definitions of Main Variables}

$\Theta \quad$ Logarithm of residual sum of squares (scaled by number of firm-year observations) from regressions of firm total return on market and 3digit industry value-weighted indexes (constructed excluding own return) run on daily data by 3 digit industry from 1990 through 1992.

market- and industry-related information capitalization

$\varnothing \quad$ Logarithm of explained sum of squares (scaled by number of firm-year observations) from the regressions described above.

intensity

firm-specific relative to systematic information

$\Psi \quad$ Logarithm of residual sum of squares minus logarithm of explained sum of squares (both scaled by number of firm-year observations) capitalization intensity

\section{Panel B. Financing source variables}

new long-term debt over investment

new equity over investment

change in current debt \& accounts payable over

investment

new long-term debt \& equity over investment

new long-term debt \& equity plus change in current

debt \& accounts payable over investment

\section{Panel C. Control variables}

log of firm-specific ROA variation from the regressions described above.

$\Delta / d \quad$ Book value of net new long-term debt and common equity issued (1993-97) over capital expenditures; truncated below 0 and above 1.

$\Delta e \quad$ Book value of net new common equity issued (1993-97) over capital expenditures, truncated below 0 and above 1.

$\Delta s d \quad$ Change in book value of current debt and accounts payable (1993-97) over capital expenditures; truncated below 0 and above 1.

$\Delta / d \& e \quad$ Book value of net new long-term debt and common equity issued (1993-97) over capital expenditures, truncated below 0 and above 1.

$\Delta d \& e \quad B o o k$ value of net new long-term debt and common equity issued plus change in book value of current debt and accounts payable (1993-97) over capital expenditures, truncated below 0 and above 1.

$R O A \Theta \quad$ Logarithm of residual sum of squares (scaled by number of firm-year observations) from regressions of firm ROA on market and 3-digit industry value-weighted ROA indexes (constructed excluding own return) run on annual data by 3-digit industry from 1983 through 1992. ROA is the sum of income, interest expenses, and depreciation over tangible assets. Tangible assets are defined as the sum of real property, plant, estimated using recursive formula in [17], and real inventory.

$\log$ of systematic ROA variation

${ }_{R O A} \varnothing \quad$ Logarithm of explained sum of squares (scaled by number of firm-year observations) from the regressions described above.

log of firm-specific rel. to systematic ROA variation

$R O A \Psi \quad$ Logarithm of residual sum of squares minus logarithm of explained sum of squares (both scaled by number of firm-year observations) from the regressions described above

diversification

ds Diversification measured as 1990 through 1992 average of total assets weighted industry average of the number of primary 3-digit SIC industries a firm operates in.

sales-based Herfindahl index

log of industry size

$H_{s} \quad$ Three-digit industry sales Herfindahl index, an average of indexes from 1990 through 1992.

net current assets over tangible assets

$\ln (K) \quad$ Log of average from 1990 through 1992 of real property, plant, and equipment, estimated using recursive formula in [17]

leverage

$\lambda$ The ratio of the difference between book values of current assets and current liabilities to tangible assets from 1990

Tangible assets is defined as above. issued at par, scaled by tangible assets. Tangible assets are estimated using recursive formula in [17]

advertising expenditures

R\&D expenditures

adv Total from 1990 through 1992 of inflation adjusted advertising expenditures over tangible assets. Tangible assets is defined as above.

Panel D. Quality of capital allocation and valuation variables

$\dot{q} \quad$ The coefficient in regression of unexpected change in firm value on unexpected change in real total assets and controls by 3-digit industry using annual data from 1993 through 1997. Real total assets is defined as above. 


\section{Table 2}

\section{Univariate Statistics of Main Variables}

mean deviation minimum maximum

\section{Panel A. Returns variation and information capitalization intensity variables}

firm-specific stock return variation

systematic return variation

systematic rel. to firm-specific return variation

firm-specific information capitalization intensity

market- and industry-related information

capitalization intensity

firm-specific relative to systematic information capitalization intensity

$\begin{array}{lrrrr}\sigma^{2}{ }_{\varepsilon} & 0.032 & 0.043 & 0.013 & 0.418 \\ \sigma^{2}{ }_{m} & 0.008 & 0.107 & 0.001 & 0.094 \\ R^{2} & 0.211 & 0.087 & 0.040 & 0.566 \\ \Theta & -3.854 & 0.859 & -6.635 & -0.871 \\ \varnothing & -5.255 & 0.794 & -7.418 & -2.364 \\ \Psi & 1.401 & 0.549 & -0.265 & 3.184\end{array}$

Panel B. Financing source variables

new long-term debt over investment

new equity over investment

$\Delta / d \quad 0.405$

0.364

0.000

1.000

$\Delta e \quad 0.388$

0.309

0.000

1.000

$\Delta s d \quad 0.116$

0.378

0.000

1.000

new long-term debt \& equity over investment

$\Delta / d \& e \quad 0.572$

0.379

0.000

1.000

$\Delta d \& e$

0.714

0.218

1.000

\section{Panel C. Control variables}

log of firm-specific ROA variation

log of systematic ROA variation

log of firm-specific rel. to systematic ROA variation

diversification

sales-based Herfindahl index

log of fixed capital

net current assets over tangible assets

leverage

advertising expenditures

$R \& D$ expenditures

$\begin{array}{ccccc}R O A \varnothing & -0.172 & 1.036 & -5.470 & 1.918 \\ R^{\Theta} \Theta & -0.411 & 1.076 & -3.371 & 2.029 \\ R O A \Psi & 0.239 & 0.722 & -2.651 & 2.419 \\ d s & 1.262 & 0.021 & 1.143 & 1.297 \\ H_{s} & 0.121 & 0.128 & 0.004 & 0.925 \\ \ln (K) & 8.357 & 1.907 & 3.701 & 13.87 \\ \bar{\lambda} & 0.320 & 0.474 & -2.701 & 2.309 \\ \text { lev } & 0.697 & 0.313 & 0.000 & 1.230 \\ \text { adv } & 0.026 & 0.446 & 0.000 & 0.295 \\ r \& d & 0.036 & 0.092 & 0.000 & 0.641 \\ \text { variables } & & & \\ \dot{q} & 0.580 & 0.628 & -1.890 & 2.221 \\ (\dot{q}-1)^{2} & 0.568 & 1.284 & 0.000 & 8.352 \\ |\dot{q}-1| & 0.517 & 0.549 & 0.004 & 3.221\end{array}$

Panel D. Quality of capital allocation and valuation variables

marginal $q$

squared deviation of marginal $q$ from one

absolute deviation of marginal $q$ from one
Note: this table reports means, standard deviations, min, and max of main variables. Refer to Table 1 for variable definitions. Sample is 214 three-digit industries for all variables. Panel B and Panel D samples are constructed using 1993-1997 data and consist of 214 three-digit industries based on 6,375 firms. Panel A and Panel $C\left(\boldsymbol{d} \boldsymbol{s}, \boldsymbol{H}_{\boldsymbol{s}}\right.$, $\left.\ln (\boldsymbol{K}), \lambda_{i}, \boldsymbol{a d v}, \boldsymbol{r \& d}\right)$ sample is constructed using 1990-1992 data and consists of 214 three-digit industries based on 6,021 firms. lev is based on 1992 data. ROA $\varnothing,{ }_{\text {ROA }} \Theta$, and ${ }_{\text {ROA }} \Psi$ sample is constructed using $1983-1992$ data and consists of 214 three-digit industries based on 5,680 firms. Finance industries (SIC code 6000 - 6999) are omitted. 


\section{Table 3a}

\section{Simple Correlation Coefficients of External Financing Variables with Each Other and with Information Capitalization Intensity Variables}

\section{Panel A. Correlation Matrix of Financing Source Variables}

\begin{tabular}{|c|c|c|c|c|c|c|}
\hline \multirow[t]{2}{*}{$\Delta / d$} & $\Delta e$ & $\Delta s d$ & $\Delta / d \& e$ & \multicolumn{3}{|l|}{$\Delta d \& e$} \\
\hline & $\begin{array}{l}0.467 \\
(0.00)\end{array}$ & $\begin{array}{l}0.350 \\
(0.00)\end{array}$ & $\begin{array}{l}0.867 \\
(0.00)\end{array}$ & $\begin{array}{l}0.516 \\
(0.00)\end{array}$ & $\Delta / d$ & new long-term debt issued over investment \\
\hline & & $\begin{array}{l}0.345 \\
(0.00)\end{array}$ & $\begin{array}{l}0.600 \\
(0.00)\end{array}$ & $\begin{array}{l}\mathbf{0 . 4 3 3} \\
(0.00)\end{array}$ & $\Delta e$ & new equity issued over investment \\
\hline & & & $\begin{array}{l}0.427 \\
(0.00)\end{array}$ & $\begin{array}{l}0.647 \\
(0.00)\end{array}$ & $\Delta s d$ & $\begin{array}{l}\text { change in current debt and accounts payable over } \\
\text { investment }\end{array}$ \\
\hline & & & & $\begin{array}{l}0.433 \\
(0.00)\end{array}$ & $\begin{array}{l}\Delta / d \& e \\
\Delta d \& e\end{array}$ & $\begin{array}{l}\text { new long-term debt \& equity issued over investment } \\
\text { new long-term debt \& equity issued plus change in } \\
\text { current debt and accounts payable over investment }\end{array}$ \\
\hline
\end{tabular}

Panel B. Correlation of Financing Source with Information Capitalization Intensity Variables

\begin{tabular}{ccccc|ccl}
$\Delta / d$ & $\Delta e$ & $\Delta / d \& e$ & $\Delta s d$ & $\Delta d \& e$ & & \\
\hline $\mathbf{0 . 1 8 3}$ & $\mathbf{0 . 4 1 3}$ & $\mathbf{0 . 2 5 4}$ & $\mathbf{0 . 1 8 4}$ & $\mathbf{0 . 1 4 9}$ & $\Theta$ & firm-specific information capitalization intensity \\
$(0.01)$ & $(0.00)$ & $(0.00)$ & $(0.01)$ & $(0.03)$ & & \\
0.087 & $\mathbf{0 . 3 4 2}$ & $\mathbf{0 . 1 8 3}$ & $\mathbf{0 . 2 1 7}$ & $\mathbf{0 . 1 3 5}$ & $\varnothing$ & market- and industry-related information capitalization \\
$(0.20)$ & $(0.00)$ & $(0.00)$ & $(0.00)$ & $(0.05)$ & & intensity \\
$\mathbf{0 . 1 6 0}$ & $\mathbf{0 . 1 5 1}$ & $\mathbf{0 . 1 3 3}$ & -0.027 & $\mathbf{0 . 1 3 7}$ & $\Psi$ & firm-specific relative to systematic information \\
$(0.02)$ & $(0.03)$ & $(0.05)$ & $(0.68)$ & $(0.05)$ & $\Psi$ & capitalization intensity \\
\hline
\end{tabular}

Note: financing source variables $(\Delta \boldsymbol{l d}, \Delta \boldsymbol{e}, \Delta \boldsymbol{l d} \boldsymbol{\&} \boldsymbol{e}, \Delta \boldsymbol{s d}, \Delta \boldsymbol{d} \boldsymbol{\&} \boldsymbol{e})$ are constructed using 1993-1997 data and based on a sample consisting of 214 three-digit industries (6,375 firms). Information capitalization intensity measures $(\Theta, \varnothing$, $\Psi)$ are constructed using 1990-1992 data and based on a sample consisting of 214 three-digit industries (6,021 firms). Finance industries (SIC code 6000 - 6999) are omitted. Refer to Table 1 for variable definitions.

Correlation coefficients are based on 214 three-digit industries sample. Numbers in parentheses are probability levels at which the null hypothesis of zero correlation is rejected. Coefficients significant at $10 \%$ or better are in boldface. 


\section{Table 3b}

\section{Simple Correlation Coefficients of Main Control Variables with Information Capitalization Intensity Variables and with Each Other}

\begin{tabular}{|c|c|c|c|c|c|c|c|c|c|c|c|}
\hline$R O A \Theta$ & $R O A \varnothing$ & $R O A \Psi$ & $d s$ & $H_{s}$ & $\ln (K)$ & $\lambda$ & lev & $a d v$ & $r \& d$ & & \\
\hline 0.363 & 0.230 & 0.182 & -0.101 & -0.219 & -0.243 & 0.090 & 0.080 & 0.148 & 0.058 & $\Theta$ & firm-specific information \\
\hline$(0.00)$ & $(0.00)$ & $(0.03)$ & $(0.10)$ & $(0.00)$ & $(0.00)$ & $(0.18)$ & $(0.27)$ & $(0.03)$ & $(0.40)$ & & capitalization intensity \\
\hline 0.204 & 0.116 & 0.121 & -0.093 & -0.173 & -0.219 & 0.070 & 0.104 & 0.089 & 0.020 & $\varnothing$ & systematic information \\
\hline$(0.00)$ & $(0.08)$ & $(0.07)$ & $(0.17)$ & $(0.01)$ & $(0.00)$ & $(0.30)$ & $(0.12)$ & $(0.20)$ & $(0.77)$ & & capitalization intensity \\
\hline \multirow{12}{*}{$\begin{array}{l}0.276 \\
(0.00)\end{array}$} & 0.194 & 0.110 & -0.120 & -0.093 & -0.063 & 0.031 & 0.020 & 0.104 & 0.062 & $\Psi$ & firm-specific rel. to systematic \\
\hline & $(0.01)$ & $(0.10)$ & $(0.09)$ & $(0.16)$ & $(0.35)$ & $(0.60)$ & $(0.74)$ & $(0.13)$ & $(0.37)$ & & info. capitalization intensity \\
\hline & $\begin{array}{l}\mathbf{0 . 7 7 1} \\
(0.00)\end{array}$ & $\begin{array}{l}\mathbf{0 . 2 9 6} \\
(0.00)\end{array}$ & $\begin{array}{r}-0.182 \\
(0.01)\end{array}$ & $\begin{array}{r}-0.348 \\
(0.00)\end{array}$ & $\begin{array}{l}0.018 \\
(0.79)\end{array}$ & $\begin{array}{r}-0.117 \\
(0.08)\end{array}$ & $\begin{array}{l}0.053 \\
(0.40)\end{array}$ & $\begin{array}{l}0.059 \\
(0.39)\end{array}$ & $\begin{array}{r}-0.029 \\
(0.68)\end{array}$ & $R O A \Theta$ & $\begin{array}{l}\log \text { of firm-specific ROA } \\
\text { variation }\end{array}$ \\
\hline & & $\begin{array}{r}-0.378 \\
(0.00)\end{array}$ & $\begin{array}{r}-0.291 \\
(0.00)\end{array}$ & $\begin{array}{l}-0.21 \\
(0.00)\end{array}$ & $\begin{array}{l}0.061 \\
(0.36)\end{array}$ & $\begin{array}{r}-0.094 \\
(0.17)\end{array}$ & $\begin{array}{l}0.155 \\
(0.00)\end{array}$ & $\begin{array}{r}-0.060 \\
(0.38)\end{array}$ & $\begin{array}{r}-0.059 \\
(0.39)\end{array}$ & $R O A \varnothing$ & $\begin{array}{l}\text { log of systematic ROA } \\
\text { variation }\end{array}$ \\
\hline & & & $\begin{array}{r}-0.172 \\
(0.00)\end{array}$ & $\begin{array}{r}-0.191 \\
(0.00)\end{array}$ & $\begin{array}{r}-0.066 \\
(0.33)\end{array}$ & $\begin{array}{l}0.022 \\
(0.74)\end{array}$ & $\begin{array}{r}-0.121 \\
(0.07)\end{array}$ & $\begin{array}{l}0.174 \\
(0.01)\end{array}$ & $\begin{array}{l}0.048 \\
(0.50)\end{array}$ & $R O A \Psi$ & $\begin{array}{l}\text { log of firm-specific rel. to } \\
\text { systematic ROA variation }\end{array}$ \\
\hline & & & & $\begin{array}{r}-0.080 \\
(0.25)\end{array}$ & $\begin{array}{l}\mathbf{0 . 2 5 7} \\
(0.00)\end{array}$ & $\begin{array}{l}0.081 \\
(0.24)\end{array}$ & $\begin{array}{l}-0.111 \\
(0.10)\end{array}$ & $\begin{array}{l}0.095 \\
(0.16)\end{array}$ & $\begin{array}{l}0.023 \\
(0.73)\end{array}$ & $d s$ & Diversification \\
\hline & & & & & $\begin{array}{l}\mathbf{0 . 1 1 2} \\
(0.10)\end{array}$ & $\begin{array}{l}\mathbf{0 . 0 4 4} \\
(0.00)\end{array}$ & $\begin{array}{l}0.076 \\
(0.25)\end{array}$ & $\begin{array}{r}-0.138 \\
(0.05)\end{array}$ & $\begin{array}{r}-0.045 \\
(0.51)\end{array}$ & $H_{s}$ & sales-based Herfindahl index \\
\hline & & & & & & $\begin{array}{r}-0.359 \\
(0.00)\end{array}$ & $\begin{array}{l}0.066 \\
(0.32)\end{array}$ & $\begin{array}{l}0.045 \\
(0.51)\end{array}$ & $\begin{array}{r}-0.081 \\
(0.24)\end{array}$ & $\ln (K)$ & log of fixed capital \\
\hline & & & & & & & $\begin{array}{r}-0.207 \\
(0.00)\end{array}$ & $\begin{array}{l}0.141 \\
(0.00)\end{array}$ & $\begin{array}{l}0.345 \\
(0.00)\end{array}$ & $\lambda$ & $\begin{array}{l}\text { net current assets over } \\
\text { tangible assets }\end{array}$ \\
\hline & & & & & & & & $\begin{array}{r}-0.361 \\
(0.00)\end{array}$ & $\begin{array}{r}-0.132 \\
(0.04)\end{array}$ & lev & leverage \\
\hline & & & & & & & & & $\begin{array}{l}0.111 \\
(0.10)\end{array}$ & $a d v$ & advertising expenditures \\
\hline & & & & & & & & & & $r \& d$ & $R \& D$ expenditures \\
\hline
\end{tabular}

Note: $\left(\boldsymbol{d} \boldsymbol{s}, \boldsymbol{H}_{\boldsymbol{s}}, \boldsymbol{l n}(\boldsymbol{K}), \lambda_{i}, \boldsymbol{a d v}, \boldsymbol{r} \& \boldsymbol{d}\right)$ sample is constructed using 1990-1992 data and consists of 214 three-digit industries based on 6,021 firms. lev is based on 1992 data. ROA $\varnothing,{ }_{R O A} \Theta$, and $\boldsymbol{R O A} \Psi$ sample is constructed using 1983-1992 data and consists of 214 three-digit industries based on 5,680 firms. Information capitalization intensity measures $(\Theta, \varnothing, \Psi)$ are constructed using 1990-1992 data and based on a sample consisting of 214 three-digit industries (6,021 firms). Finance industries (SIC code 6000 - 6999) are omitted. Refer to Table 1 for variable definitions.

Correlation coefficients are based on 214 three-digit industries sample. Numbers in parentheses are probability levels at which the null hypothesis of zero correlation is rejected. Coefficients significant at $10 \%$ or better are in boldface. 


\section{Table 3c}

\section{Simple Correlation Coefficients of External Financing Variables with Control Variables}

\begin{tabular}{|c|c|c|c|c|c|c|}
\hline$\Delta / d$ & $\Delta e$ & $\Delta s d$ & $\Delta / d \& e$ & $\Delta d \& e$ & & \\
\hline $\begin{array}{r}-0.075 \\
(0.28)\end{array}$ & $\begin{array}{r}-0.117 \\
(0.09)\end{array}$ & $\begin{array}{l}0.039 \\
(0.57)\end{array}$ & $\begin{array}{c}-0.083 \\
(0.23)\end{array}$ & $\begin{array}{l}-0.053 \\
(0.44)\end{array}$ & Ds & Diversification \\
\hline $\begin{array}{l}0.097 \\
(0.12)\end{array}$ & $\begin{array}{l}-0.031 \\
(0.64)\end{array}$ & $\begin{array}{c}-0.002 \\
(0.97)\end{array}$ & $\begin{array}{r}-0.012 \\
(0.86)\end{array}$ & $\begin{array}{l}-0.116 \\
(0.08)\end{array}$ & $H_{s}$ & sales-based Herfindahl index \\
\hline $\begin{array}{r}-0.323 \\
(0.00)\end{array}$ & $\begin{array}{r}-0.542 \\
(0.00)\end{array}$ & $\begin{array}{r}-0.250 \\
(0.00)\end{array}$ & $\begin{array}{r}-0.369 \\
(0.00)\end{array}$ & $\begin{array}{l}-0.115 \\
(0.08)\end{array}$ & $\ln (K)$ & $\log$ of fixed capital \\
\hline $\begin{array}{l}\mathbf{0 . 2 0 1} \\
(0.00)\end{array}$ & $\begin{array}{l}0.272 \\
(0.00)\end{array}$ & $\begin{array}{l}\mathbf{0 . 1 7 3} \\
(0.00)\end{array}$ & $\begin{array}{l}\mathbf{0 . 1 8 5} \\
(0.00)\end{array}$ & $\begin{array}{l}\mathbf{0 . 2 8 0} \\
(0.00)\end{array}$ & $\lambda$ & net current assets over tangible assets \\
\hline $\begin{array}{r}-0.176 \\
(0.00)\end{array}$ & $\begin{array}{l}0.081 \\
(0.24)\end{array}$ & $\begin{array}{c}-0.112 \\
(0.11)\end{array}$ & $\begin{array}{r}-0.042 \\
(0.53)\end{array}$ & $\begin{array}{l}0.028 \\
(0.69)\end{array}$ & Lev & leverage \\
\hline $\begin{array}{r}-0.053 \\
(0.44)\end{array}$ & $\begin{array}{l}\mathbf{0 . 1 1 3} \\
(0.10)\end{array}$ & $\begin{array}{l}0.014 \\
(0.84)\end{array}$ & $\begin{array}{l}\mathbf{0 . 0 6 8} \\
(0.32)\end{array}$ & $\begin{array}{l}-0.028 \\
(0.69)\end{array}$ & $A d v$ & advertising expenditures \\
\hline $\begin{array}{l}-0.048 \\
(0.48)\end{array}$ & $\begin{array}{l}0.062 \\
(0.37)\end{array}$ & $\begin{array}{l}0.111 \\
(0.10)\end{array}$ & $\begin{array}{l}0.023 \\
(0.74)\end{array}$ & $\begin{array}{l}0.037 \\
(0.60)\end{array}$ & $r \& d$ & research and development expenditures \\
\hline $\begin{array}{l}\mathbf{0 . 1 3 5} \\
(0.05)\end{array}$ & $\begin{array}{l}\mathbf{0 . 2 9 8} \\
(0.00)\end{array}$ & $\begin{array}{c}-0.015 \\
(0.87)\end{array}$ & $\begin{array}{l}\mathbf{0 . 2 1 1} \\
(0.00)\end{array}$ & $\begin{array}{l}\mathbf{0 . 1 4 9} \\
(0.03)\end{array}$ & $R O A \Theta$ & log of firm-specific ROA variation \\
\hline $\begin{array}{l}0.034 \\
(0.62)\end{array}$ & $\begin{array}{l}\mathbf{0 . 1 7 9} \\
(0.01)\end{array}$ & $\begin{array}{r}-0.034 \\
(0.62)\end{array}$ & $\begin{array}{l}0.085 \\
(0.22)\end{array}$ & $\begin{array}{l}\mathbf{0 . 1 1 3} \\
(0.10)\end{array}$ & $R O A \varnothing$ & log of systematic ROA variation \\
\hline $\begin{array}{l}\mathbf{0 . 1 4 4} \\
(0.04)\end{array}$ & $\begin{array}{l}\mathbf{0 . 1 6 1} \\
(0.02)\end{array}$ & $\begin{array}{l}0.034 \\
(0.61)\end{array}$ & $\begin{array}{l}\mathbf{0 . 1 7 7} \\
(0.01)\end{array}$ & $\begin{array}{l}0.048 \\
(0.48)\end{array}$ & $R O A \Psi$ & $\begin{array}{l}\text { log of firm-specific relative to systematic } \\
\text { ROA variation }\end{array}$ \\
\hline
\end{tabular}

Note: financing source variables are: new long-term debt over investment, $\Delta l d ;$ new equity over investment, $\Delta$ e; new long-term debt \& equity over investment, $\Delta$ ld\& $;$ change in current debt \& accounts payable over investment, $\Delta$ sd; and new long term debt \& equity plus change in current debt \& accounts payable over investment, $\Delta d \& e$. Financing source variables ( $\Delta \boldsymbol{l d}, \Delta \boldsymbol{e}, \Delta \boldsymbol{l d} \& \boldsymbol{e}, \Delta \boldsymbol{s} \boldsymbol{d}, \Delta \boldsymbol{d} \& \boldsymbol{e})$ are constructed using 1993-1997 data and based on a sample consisting of 214 three-digit industries (6,375 firms). (ds, $\left.\boldsymbol{H}_{\boldsymbol{s}}, \boldsymbol{l n}(\boldsymbol{K}), \hbar_{i}, \boldsymbol{a d v}, \boldsymbol{r} \& \boldsymbol{d}\right)$ sample is constructed using $1990-1992$ data and consists of 214 three-digit industries based on 6,021 firms. lev is based on 1992 data. RоA $\varnothing, \boldsymbol{R O A}_{\Theta} \Theta$, and $_{\mathrm{ROA}} \Psi$ are constructed using 1983-1992 data and consists of 214 three-digit industries based on 5,680 firms. Finance industries (SIC code 6000 - 6999) are omitted. Refer to Table 1 for variable definitions.

Numbers in parentheses are probability levels at which the null hypothesis of zero correlation is rejected. Coefficients significant at $10 \%$ or better are in boldface. 

Table 4

Tobit Regressions of Financing Source on Information Capitalization Intensity and Control Variables

\begin{tabular}{|c|c|c|c|c|c|c|c|c|c|c|c|c|c|c|c|}
\hline & 4.1 & 4.2 & 4.3 & 4.4 & 4.5 & 4.6 & 4.7 & 4.8 & 4.9 & 4.10 & 4.11 & 4.12 & 4.13 & 4.14 & 4.15 \\
\hline dependent variable & \multicolumn{3}{|c|}{$\begin{array}{c}\text { new long-term debt } \\
\text { over investment, } \\
\Delta / d\end{array}$} & \multicolumn{3}{|c|}{$\begin{array}{c}\text { new equity } \\
\text { over investment, } \\
\Delta e\end{array}$} & \multicolumn{3}{|c|}{$\begin{array}{c}\text { change in current debt \& } \\
\text { accounts payable over } \\
\text { investment, } \Delta \text { sd }\end{array}$} & \multicolumn{3}{|c|}{$\begin{array}{l}\text { new long-term debt } \\
\& \text { equity over } \\
\text { investment, } \Delta / d \& e\end{array}$} & \multicolumn{3}{|c|}{$\begin{array}{c}\text { new long-term debt, } \\
\text { equity, cur. debt \& acc. } \\
\text { payable / invest, } \Delta d \& e\end{array}$} \\
\hline $\begin{array}{l}\text { firm-specific information } \\
\text { capitalization intensity } \Theta\end{array}$ & $\begin{array}{l}\mathbf{0 . 1 7 9} \\
(0.01)\end{array}$ & $\begin{array}{l}0.105 \\
(0.09)\end{array}$ & - & $\begin{array}{l}\mathbf{0 . 1 5 9} \\
(0.04)\end{array}$ & $\begin{array}{l}\mathbf{0 . 0 4 0} \\
(0.10)\end{array}$ & - & $\begin{array}{l}\mathbf{0 . 0 2 0} \\
(0.05)\end{array}$ & $\begin{array}{l}\mathbf{0 . 0 1 9} \\
(0.08)\end{array}$ & - & $\begin{array}{l}\mathbf{0 . 2 1 7} \\
(0.01)\end{array}$ & $\begin{array}{l}\mathbf{0 . 0 5 3} \\
(0.10)\end{array}$ & - & $\begin{array}{l}\mathbf{0 . 2 4 4} \\
(0.00)\end{array}$ & $\begin{array}{l}\mathbf{0 . 0 4 0} \\
(0.05)\end{array}$ & - \\
\hline $\begin{array}{l}\text { market- \& industry information } \\
\text { capitalization intensity } \varnothing\end{array}$ & $\begin{array}{l}-0.088 \\
(0.25)\end{array}$ & $\begin{array}{l}-0.082 \\
(0.22)\end{array}$ & - & $\begin{array}{l}0.015 \\
(0.74)\end{array}$ & $\begin{array}{l}0.015 \\
(0.69)\end{array}$ & - & $\begin{array}{l}0.057 \\
(0.21)\end{array}$ & $\begin{array}{l}0.053 \\
(0.22)\end{array}$ & - & $\begin{array}{l}0.032 \\
(0.72)\end{array}$ & $\begin{array}{l}0.029 \\
(0.71)\end{array}$ & - & $\begin{array}{l}0.052 \\
(0.85)\end{array}$ & $\begin{array}{l}0.076 \\
(0.73)\end{array}$ & - \\
\hline $\begin{array}{c}\text { firm-specific rel. to systematic } \\
\text { info. cap. intensity }\end{array} \Psi$ & - & - & $\begin{array}{l}0.108 \\
(0.03)\end{array}$ & - & - & $\begin{array}{l}\mathbf{0 . 0 4 6} \\
(0.10)\end{array}$ & - & - & $\begin{array}{l}0.038 \\
(0.20)\end{array}$ & - & - & $\begin{array}{l}\mathbf{0 . 0 7 1} \\
(0.05)\end{array}$ & - & - & $\begin{array}{l}0.052 \\
(0.10)\end{array}$ \\
\hline $\begin{array}{c}\log \text { of firm-specific } R O A \\
\text { variation } R O A \Theta\end{array}$ & - & $\begin{array}{l}\mathbf{0 . 1 4 1} \\
(0.01)\end{array}$ & - & - & $\begin{array}{l}\mathbf{0 . 0 7 8} \\
(0.00)\end{array}$ & - & - & $\begin{array}{l}-0.010 \\
(0.70)\end{array}$ & - & - & $\begin{array}{l}\mathbf{0 . 1 9 0} \\
(0.00)\end{array}$ & & - & $\begin{array}{l}\mathbf{0 . 3 1 5} \\
(0.10)\end{array}$ & - \\
\hline $\begin{array}{l}\log \text { of systematic } R O A \\
\text { variation } R O A \varnothing\end{array}$ & - & $\begin{array}{l}-0.123 \\
(0.05)\end{array}$ & - & - & $\begin{array}{l}-0.010 \\
(0.94)\end{array}$ & - & - & $\begin{array}{l}0.013 \\
(0.72)\end{array}$ & - & - & $\begin{array}{l}\mathbf{0 . 1 1 6} \\
(0.05)\end{array}$ & & - & $\begin{array}{l}0.015 \\
(0.92)\end{array}$ & - \\
\hline $\begin{array}{c}\text { log of firm-specific rel. to syst. } \\
\text { ROA variation }\end{array}$ & - & - & $\begin{array}{l}\mathbf{0 . 1 3 3} \\
(0.00)\end{array}$ & - & - & $\begin{array}{l}0.034 \\
(0.22)\end{array}$ & - & - & $\begin{array}{l}0.018 \\
(0.75)\end{array}$ & - & - & $\begin{array}{l}\mathbf{0 . 1 4 0} \\
(0.01)\end{array}$ & - & - & $\begin{array}{l}0.126 \\
(0.45)\end{array}$ \\
\hline diversification ds & - & $\begin{array}{l}-1.511 \\
(0.42)\end{array}$ & $\begin{array}{c}-1.843 \\
(0.30)\end{array}$ & - & $\begin{array}{l}-0.626 \\
(0.46)\end{array}$ & $\begin{array}{r}-1.610 \\
(0.10)\end{array}$ & - & $\begin{array}{l}0.640 \\
(0.54)\end{array}$ & $\begin{array}{l}0.426 \\
(0.72)\end{array}$ & - & $\begin{array}{l}1.193 \\
(0.54)\end{array}$ & $\begin{array}{l}2.060 \\
(0.30)\end{array}$ & - & $\begin{array}{l}2.470 \\
(0.71)\end{array}$ & $\begin{array}{l}5.913 \\
(0.33)\end{array}$ \\
\hline Herfindahl index $H_{s}$ & - & $\begin{array}{l}0.048 \\
(0.91)\end{array}$ & $\begin{array}{l}-0.071 \\
(0.80)\end{array}$ & - & $\begin{array}{l}-0.473 \\
(0.01)\end{array}$ & $\begin{array}{l}-0.788 \\
(0.01)\end{array}$ & - & $\begin{array}{l}0.262 \\
(0.20)\end{array}$ & $\begin{array}{l}\mathbf{0 . 3 8 8} \\
(0.05)\end{array}$ & - & $\begin{array}{c}-0.702 \\
(0.10)\end{array}$ & $\begin{array}{r}-0.970 \\
(0.00)\end{array}$ & - & $\begin{array}{l}0.512 \\
(0.66)\end{array}$ & $\begin{array}{l}0.922 \\
(0.22)\end{array}$ \\
\hline $\log$ of fixed capital $\ln (K)$ & - & $\begin{array}{l}-0.060 \\
(0.00)\end{array}$ & $\begin{array}{l}-0.072 \\
(0.00)\end{array}$ & - & $\begin{array}{l}-0.106 \\
(0.01)\end{array}$ & $\begin{array}{l}-0.116 \\
(0.01)\end{array}$ & - & $\begin{array}{l}-0.028 \\
(0.16)\end{array}$ & $\begin{array}{l}0.030 \\
(0.05)\end{array}$ & - & $\begin{array}{l}\mathbf{0 . 1 2 1} \\
(0.03)\end{array}$ & $\begin{array}{l}\mathbf{0 . 1 3 1} \\
(0.03)\end{array}$ & - & $\begin{array}{l}\mathbf{0 . 1 4 6} \\
(0.09)\end{array}$ & $\begin{array}{l}\mathbf{0 . 1 7 5} \\
(0.00)\end{array}$ \\
\hline $\begin{array}{c}\text { net current assets over } \\
\text { tangible assets }\end{array} \lambda_{i}$ & - & $\begin{array}{l}0.120 \\
(0.15)\end{array}$ & $\begin{array}{l}0.115 \\
(0.20)\end{array}$ & - & $\begin{array}{l}0.050 \\
(0.18)\end{array}$ & $\begin{array}{l}0.034 \\
(0.47)\end{array}$ & - & $\begin{array}{l}\mathbf{0 . 2 0 2} \\
(0.03)\end{array}$ & $\begin{array}{l}0.201 \\
(0.01)\end{array}$ & - & $\begin{array}{l}0.153 \\
(0.18)\end{array}$ & $\begin{array}{l}0.138 \\
(0.22)\end{array}$ & - & $\begin{array}{l}\mathbf{1 . 2 7 0} \\
(0.01)\end{array}$ & $\begin{array}{l}1.199 \\
(0.00)\end{array}$ \\
\hline leverage lev & - & $\begin{array}{l}-0.866 \\
(0.01)\end{array}$ & $\begin{array}{l}-0.876 \\
(0.00)\end{array}$ & - & $\begin{array}{l}0.060 \\
(0.68)\end{array}$ & $\begin{array}{l}0.100 \\
(0.60)\end{array}$ & - & $\begin{array}{l}0.012 \\
(0.99)\end{array}$ & $\begin{array}{l}0.019 \\
(0.90)\end{array}$ & - & $\begin{array}{l}0.599 \\
(0.10)\end{array}$ & $\begin{array}{l}0.640 \\
(0.10)\end{array}$ & - & $\begin{array}{l}0.148 \\
(0.90)\end{array}$ & $\begin{array}{l}0.330 \\
(0.78)\end{array}$ \\
\hline advertising expenditures $a d v$ & - & $\begin{array}{l}-0.099 \\
(0.91)\end{array}$ & $\begin{array}{l}-0.032 \\
(0.96)\end{array}$ & - & $\begin{array}{l}\mathbf{0 . 7 2 9} \\
(0.10)\end{array}$ & $\begin{array}{l}0.882 \\
(0.10)\end{array}$ & - & $\begin{array}{l}-0.299 \\
(0.55)\end{array}$ & $\begin{array}{l}0.223 \\
(0.68)\end{array}$ & - & $\begin{array}{l}1.152 \\
(0.23)\end{array}$ & $\begin{array}{l}1.280 \\
(0.22)\end{array}$ & - & $\begin{array}{l}2.934 \\
(0.30)\end{array}$ & $\begin{array}{l}2.752 \\
(0.32)\end{array}$ \\
\hline$R \& D$ expenditures $\quad r \& d$ & - & $\begin{array}{l}-0.563 \\
(0.17) \\
\end{array}$ & $\begin{array}{l}-0.563 \\
(0.19) \\
\end{array}$ & - & $\begin{array}{c}-0.194 \\
(0.53)\end{array}$ & $\begin{array}{c}-0.156 \\
(0.45) \\
\end{array}$ & - & $\begin{array}{l}0.139 \\
(0.55) \\
\end{array}$ & $\begin{array}{l}0.142 \\
(0.54) \\
\end{array}$ & - & $\begin{array}{l}0.602 \\
(0.20) \\
\end{array}$ & $\begin{array}{l}0.640 \\
(0.19) \\
\end{array}$ & - & $\begin{array}{l}1.494 \\
(0.30) \\
\end{array}$ & $\begin{array}{l}1.587 \\
(0.26) \\
\end{array}$ \\
\hline chi-squared-statistics & $\begin{array}{l}8.270 \\
(0.01)\end{array}$ & $\begin{array}{c}40.613 \\
(0.00)\end{array}$ & $\begin{array}{c}39.042 \\
(0.00)\end{array}$ & $\begin{array}{c}39.480 \\
(0.00)\end{array}$ & $\begin{array}{c}129.41 \\
(0.00)\end{array}$ & $\begin{array}{c}110.89 \\
(0.00)\end{array}$ & $\begin{array}{l}6.920 \\
(0.03)\end{array}$ & $\begin{array}{c}32.111 \\
(0.00)\end{array}$ & $\begin{array}{c}28.783 \\
(0.00)\end{array}$ & $\begin{array}{c}13.230 \\
(0.00)\end{array}$ & $\begin{array}{c}\mathbf{5 4 . 8 9 0} \\
(0.00)\end{array}$ & $\begin{array}{c}52.903 \\
(0.00)\end{array}$ & $\begin{array}{c}33.370 \\
(0.18)\end{array}$ & $\begin{array}{c}107.90 \\
(0.00)\end{array}$ & $\begin{array}{c}103.22 \\
(0.00)\end{array}$ \\
\hline pseudo $R^{2}$ & 0.022 & 0.108 & 0.112 & 0.187 & 0.614 & 0.523 & 0.035 & 0.152 & 0.145 & 0.032 & 0.138 & 0.121 & 0.004 & 0.542 & 0.440 \\
\hline
\end{tabular}


Note for Table 4: this table reports the Maximum Likelihood Estimation results of Tobit regressions. Lower limit is equal to 0; upper limit is equal to 1.

Financing source variables ( $\Delta \boldsymbol{l d}, \Delta \boldsymbol{e}, \Delta \boldsymbol{l d} \boldsymbol{d} \boldsymbol{e}, \Delta \boldsymbol{s} \boldsymbol{d}, \Delta \boldsymbol{d} \& \boldsymbol{e})$ are constructed using 1993-1997 data and based on a sample consisting of 214 three-digit industries (6,375 firms). Information capitalization intensity measures $(\Theta, \varnothing, \Psi)$ are constructed using 1990-1992 data and based on a sample consisting of 214 three-digit industries (6,021 firms). $\left(\boldsymbol{d} \boldsymbol{s}, \boldsymbol{H}_{s}, \boldsymbol{l n}(\boldsymbol{K}), \lambda_{i}, \boldsymbol{a d v}, \boldsymbol{r} \& \boldsymbol{d}\right)$ sample is constructed using 1990-1992 data and consists of 214 three-digit industries based on 6,021 firms. lev is based on 1992 data. RoA $\varnothing$, ${ }_{R O A} \Theta$, and ROA $_{\Psi}$ are constructed using 1983-1992 data and consists of 214 three-digit industries based on 5,680 firms. Finance industries (SIC code 6000 - 6999) are omitted. Refer to Table 1 for variable definitions.

Numbers in parentheses are probability levels at which the null hypothesis of zero coefficient can be rejected. Coefficients significant at $10 \%$ level are in boldface.

Regressions 4.1, 4.4, 4.7, 4.10, and 4.13 include one-digit industry fixed effects, firm-specific information capitalization intensity and market-and industry-related information capitalization intensity as independent variables. Regressions 4.2, 4.5, 4.8, 4.11, and 4.14 also include log of firm-specific ROA variation, log of systematic ROA variation, diversification, Herfindahl index, log of fixed capital, net current assets over tangible assets, leverage over total assets, advertising expenditures, and $R \& D$ expenditures as control variables. Regressions 4.3, 4.6, 4.9, 4.12, and 4.15 include one-digit industry fixed effects, firm-specific rel. to systematic info. cap. intensity, log of firm-specific rel. to syst. ROA variation, diversification, Herfindahl index, log of fixed capital, net current assets over tangible assets, leverage, advertising expenditures, and R\&D expenditures as independent variables. 
Table 5

Simple Correlation Coefficients of Quality of Capital Allocation and Valuation Measures with Information Capitalization Intensity, Financing Source, Main Control Variables, and with Each Other

\begin{tabular}{|c|c|c|c|c|c|c|c|}
\hline$(\dot{q}-1)^{2}$ & $|\dot{q}-1|$ & & & $(\dot{q}-1)^{2}$ & $|\dot{q}-1|$ & \multirow[b]{2}{*}{$\Delta / d$} & \multirow[b]{2}{*}{$\begin{array}{l}\text { new long-term debt issued over } \\
\text { investment }\end{array}$} \\
\hline $\begin{array}{r}-0.148 \\
(0.03)\end{array}$ & $\begin{array}{r}-0.139 \\
(0.04)\end{array}$ & $\Theta$ & $\begin{array}{l}\text { log of firm-specific stock return } \\
\text { variation }\end{array}$ & $\begin{array}{l}-0.139 \\
(0.04)\end{array}$ & $\begin{array}{l}-0.161 \\
(0.02)\end{array}$ & & \\
\hline $\begin{array}{l}-0.070 \\
(0.30)\end{array}$ & $\begin{array}{r}-0.091 \\
(0.18)\end{array}$ & $\varnothing$ & log of systematic return variation & $\begin{array}{l}-0.134 \\
(0.05)\end{array}$ & $\begin{array}{l}-0.172 \\
(0.01)\end{array}$ & $\Delta e$ & $\begin{array}{l}\text { new equity issued over } \\
\text { investment }\end{array}$ \\
\hline $\begin{array}{r}-0.130 \\
(0.06)\end{array}$ & $\begin{array}{r}-0.087 \\
(0.20)\end{array}$ & $\Psi$ & $\begin{array}{l}\text { log of firm-specific rel. to } \\
\text { systematic return variation }\end{array}$ & $\begin{array}{l}-0.179 \\
(0.01)\end{array}$ & $\begin{array}{l}-0.198 \\
(0.00)\end{array}$ & $\Delta / d \& e$ & $\begin{array}{l}\text { new long-term debt \& equity } \\
\text { issued over investment }\end{array}$ \\
\hline $\begin{array}{l}0.046 \\
(0.50)\end{array}$ & $\begin{array}{l}0.041 \\
(0.55)\end{array}$ & $R O A \Theta$ & log of firm-specific $R O A$ variation & $\begin{array}{l}-0.098 \\
(0.15)\end{array}$ & $\begin{array}{l}-0.157 \\
(0.02)\end{array}$ & $\Delta s d$ & $\begin{array}{l}\text { change in current debt and } \\
\text { accounts payable over inv. }\end{array}$ \\
\hline $\begin{array}{r}-0.012 \\
(0.86)\end{array}$ & $\begin{array}{l}0.016 \\
(0.81)\end{array}$ & $R O A \varnothing$ & log of systematic ROA variation & -0.12 & -0.176 & 1 & $\begin{array}{l}\text { new long term debt and equity } \\
\text { issued plus change in current }\end{array}$ \\
\hline $\begin{array}{l}0.084 \\
(0.22)\end{array}$ & $\begin{array}{l}0.034 \\
(0.61)\end{array}$ & $R O A \Psi$ & $\begin{array}{l}\text { log of firm-specific rel. to } \\
\text { systematic ROA variation }\end{array}$ & $(0.08)$ & $(0.01)$ & $\angle$ & $\begin{array}{l}\text { debt and accounts payable over } \\
\text { investment }\end{array}$ \\
\hline $\begin{array}{r}-0.014 \\
(0.84)\end{array}$ & $\begin{array}{r}-0.064 \\
(0.25)\end{array}$ & $d s$ & diversification & & $\begin{array}{l}0.884 \\
(0.00)\end{array}$ & $(\dot{q}-1)^{2}$ & $\begin{array}{l}\text { squared deviation of marginal } q \\
\text { from } 1\end{array}$ \\
\hline $\begin{array}{l}0.023 \\
(0.73)\end{array}$ & $\begin{array}{l}0.015 \\
(0.86)\end{array}$ & $H_{S}$ & sales-based Herfindahl index & & & $|\dot{q}-1|$ & $\begin{array}{l}\text { absolute deviation of marginal } q \\
\text { from } 1\end{array}$ \\
\hline $\begin{array}{l}0.069 \\
(0.31)\end{array}$ & $\begin{array}{l}0.892 \\
(0.00)\end{array}$ & $\ln (K)$ & log of fixed capital & & & & \\
\hline $\begin{array}{r}-0.060 \\
(0.64)\end{array}$ & $\begin{array}{r}-0.126 \\
(0.05)\end{array}$ & $\lambda$ & $\begin{array}{l}\text { net current assets over tangible } \\
\text { assets }\end{array}$ & & & & \\
\hline $\begin{array}{r}-0.058 \\
(0.30)\end{array}$ & $\begin{array}{l}0.026 \\
(0.70)\end{array}$ & lev & leverage & & & & \\
\hline $\begin{array}{l}0.044 \\
(0.53)\end{array}$ & $\begin{array}{r}-0.017 \\
(0.82)\end{array}$ & $a d v$ & advertising expenditures & & & & \\
\hline $\begin{array}{l}0.085 \\
(0.22)\end{array}$ & $\begin{array}{l}-0.01 \\
(0.89)\end{array}$ & $r \& d$ & $R \& D$ expenditures & & & & \\
\hline
\end{tabular}




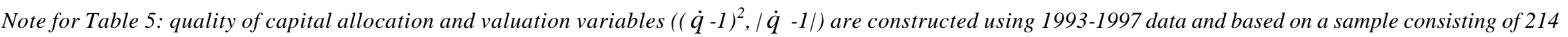

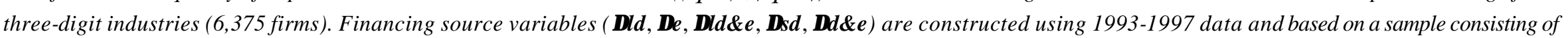

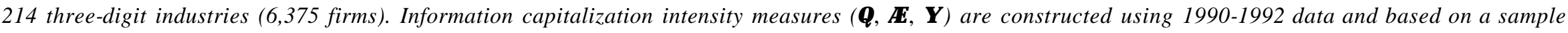

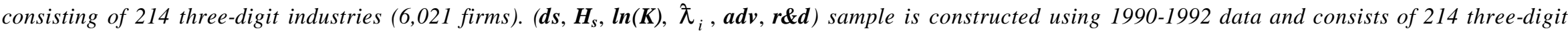

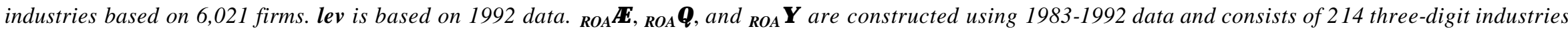
based on 5,680 firms. Finance industries (SIC code 6000 - 6999) are omitted. Refer to Table 1 for variable definitions.

Correlation coefficients are based on 214 three-digit industries sample. Numbers in parentheses are probability levels at which the null hypothesis of zero correlation is rejected. Coefficients significant at $10 \%$ or better are in boldface. 


\section{Table 6}

\section{OLS Regressions of Quality of Capital Allocation and Valuation on Information Capitalization Intensity and Control Variables}

\begin{tabular}{|c|c|c|c|c|c|c|}
\hline & 6.1 & 6.2 & 6.3 & 6.4 & 6.5 & 6.6 \\
\hline dependent variable & \multicolumn{3}{|c|}{$\begin{array}{c}\text { squared deviation of } \\
\text { marginal q from } 1,(\dot{q}-1)^{2}\end{array}$} & \multicolumn{3}{|c|}{$\begin{array}{l}\text { absolute value of deviation of } \\
\text { marginal } q \text { from } 1,|\dot{q}-1|\end{array}$} \\
\hline $\begin{array}{l}\text { firm-specific information } \\
\text { capitalization intensity } \Theta\end{array}$ & $\begin{array}{l}-0.349 \\
(0.05)\end{array}$ & $\begin{array}{l}-0.450 \\
(0.10)\end{array}$ & - & $\begin{array}{c}-0.117 \\
(0.05)\end{array}$ & $\begin{array}{l}-0.116 \\
(0.05)\end{array}$ & - \\
\hline $\begin{array}{c}\text { market- and industry-related } \\
\text { information capitalization } \\
\text { intensity }\end{array} \varnothing$ & $\begin{array}{l}0.104 \\
(0.45)\end{array}$ & $\begin{array}{l}0.163 \\
(0.30)\end{array}$ & - & $\begin{array}{l}0.008 \\
(0.91)\end{array}$ & $\begin{array}{l}0.020 \\
(0.80)\end{array}$ & - \\
\hline $\begin{array}{r}\text { firm-specific rel. to } \\
\text { systematic } \\
\text { information capitalization } \\
\text { intensity }\end{array}$ & - & - & $\begin{array}{l}-0.242 \\
(0.05)\end{array}$ & - & - & $\begin{array}{l}-0.055 \\
(0.06)\end{array}$ \\
\hline $\begin{array}{r}\text { log of firm-specific } R^{R A} \\
\text { variation } R O A \Theta\end{array}$ & - & $\begin{array}{l}0.262 \\
(0.24)\end{array}$ & - & - & $\begin{array}{l}0.063 \\
(0.40)\end{array}$ & - \\
\hline $\begin{array}{l}\log \text { of systematic } R O A \\
\text { variation ROA } \varnothing\end{array}$ & - & $\begin{array}{l}-0.081 \\
(0.45)\end{array}$ & - & - & $\begin{array}{l}-0.020 \\
(0.75)\end{array}$ & - \\
\hline $\begin{array}{l}\text { log of firm-specific rel. to } \\
\text { systematic ROA variation } R O A \Psi\end{array}$ & - & - & $\begin{array}{l}0.115 \\
(0.25)\end{array}$ & - & - & $\begin{array}{l}0.026 \\
(0.60)\end{array}$ \\
\hline diversification $d s$ & - & $\begin{array}{l}-6.150 \\
(0.18)\end{array}$ & $\begin{array}{r}-4.630 \\
(0.20)\end{array}$ & - & $\begin{array}{l}-2.166 \\
(0.30)\end{array}$ & $\begin{array}{l}-1.688 \\
(0.42)\end{array}$ \\
\hline Herfindahl index $H_{s}$ & - & $\begin{array}{l}0.714 \\
(0.23)\end{array}$ & $\begin{array}{l}0.969 \\
(0.00)\end{array}$ & - & $\begin{array}{l}0.567 \\
(0.05)\end{array}$ & $\begin{array}{l}0.674 \\
(0.00)\end{array}$ \\
\hline $\log$ of fixed capital $\ln (K)$ & - & $\begin{array}{l}0.070 \\
(0.62)\end{array}$ & $\begin{array}{l}0.140 \\
(0.25)\end{array}$ & - & $\begin{array}{l}\mathbf{0 . 0 7 7} \\
(0.05)\end{array}$ & $\begin{array}{l}0.088 \\
(0.00)\end{array}$ \\
\hline $\begin{array}{r}\text { net current assets over } \\
\text { tangible assets }\end{array} \lambda_{i}$ & - & $\begin{array}{l}0.017 \\
(0.88)\end{array}$ & $\begin{array}{l}0.053 \\
(0.77)\end{array}$ & - & $\begin{array}{l}-0.044 \\
(0.60)\end{array}$ & $\begin{array}{l}-0.032 \\
(0.66)\end{array}$ \\
\hline leverage lev & - & $\begin{array}{l}-1.342 \\
(0.10)\end{array}$ & $\begin{array}{r}-1.333 \\
(0.10)\end{array}$ & - & $\begin{array}{l}-0.420 \\
(0.19)\end{array}$ & $\begin{array}{l}-0.406 \\
(0.19)\end{array}$ \\
\hline advertising expenditures adv & - & $\begin{array}{l}0.308 \\
(0.90)\end{array}$ & $\begin{array}{l}0.223 \\
(0.89)\end{array}$ & - & $\begin{array}{l}-0.475 \\
(0.59)\end{array}$ & $\begin{array}{l}-0.510 \\
(0.58)\end{array}$ \\
\hline$R \& D$ expenditures $\quad r \& d$ & - & $\begin{array}{l}1.490 \\
(0.46)\end{array}$ & $\begin{array}{l}1.543 \\
(0.44)\end{array}$ & - & $\begin{array}{l}0.195 \\
(0.71)\end{array}$ & $\begin{array}{l}0.196 \\
(0.71)\end{array}$ \\
\hline F-statistics & $\begin{array}{l}38.750 \\
(0.00)\end{array}$ & $\begin{array}{c}21.024 \\
(0.00)\end{array}$ & $\begin{array}{c}14.320 \\
(0.00)\end{array}$ & $\begin{array}{c}48.150 \\
(0.00)\end{array}$ & $\begin{array}{c}34.320 \\
(0.00)\end{array}$ & $\begin{array}{c}24.872 \\
(0.00)\end{array}$ \\
\hline Regression $R^{2}$ & 0.094 & 0.178 & 0.142 & 0.156 & 0.229 & 0.208 \\
\hline
\end{tabular}


Note for Table 6: this table reports OLS regression estimation results.

Quality of capital allocation and valuation variables $\left((\dot{q}-1)^{2},|\dot{q}-1|\right)$ are constructed using $1993-1997$ data and based on a sample consisting of 214 three-digit industries (6,375 firms). Information capitalization intensity measures ( $\Theta, \varnothing, \Psi)$ are constructed using 1990-1992 data and based on a sample consisting of 214 three-digit industries (6,021 firms). (ds, $\left.\boldsymbol{H}_{s}, \boldsymbol{l n}(\boldsymbol{K}), \lambda_{i}, \boldsymbol{a d v}, \boldsymbol{r \& d}\right)$ sample is constructed using 1990-1992 data and consists of 214 three-digit industries based on 6,021 firms. lev is based on 1992 data. ROA $\varnothing,{ }_{\text {ROA }} \Theta$, and ${ }_{\text {ROA }} \Psi$ are constructed using 1983-1992 data and consists of 214 three-digit industries based on 5,680 firms. Finance industries (SIC code 6000 - 6999) are omitted. Refer to Table 1 for variable definitions.

Numbers in parentheses are probability levels based on Newey-West standard errors at which the null hypothesis of zero coefficient can be rejected. Coefficients significant at 10\% level are in boldface. All regressions include one-digit SIC industry fixed effects.

Regressions 6.1 and 6.4 include one-digit industry fixed effects, firm-specific information capitalization intensity and market-and industry-related information capitalization intensity as independent variables. Regressions 6.2 and 6.5 also include log of firm-specific ROA variation, log of systematic ROA variation, diversification, Herfindahl index, log of fixed capital, net current assets over tangible assets, leverage, advertising expenditures, and $R \& D$ expenditures as control variables. Regressions 6.3 and 6.6 include one-digit industry fixed effects, firm-specific rel. to systematic info. cap. intensity, log of firm-specific relative to systematic. ROA variation, diversification, Herfindahl index, log of fixed capital, net current assets over tangible assets, leverage, advertising expenditures, and $R \& D$ expenditures as independent variables. 